Additional Perspectives articles for Influenza: The Cutting Edge book collection are available at http://perspectivesinmedicine.cshlp.org/cgi/collection/influenza_the_cutting_edge.

\title{
Hemagglutinin Structure and Activities
}

\author{
Steven J. Gamblin, Sébastien G. Vachieri, Xiaoli Xiong, Jie Zhang, Stephen R. Martin, \\ and John J. Skehel
}

Structural Biology of Disease Processes Laboratory, The Francis Crick Institute, London NW1 1AT, United Kingdom

Correspondence: John.Skehel@crick.ac.uk

Hemagglutinins (HAs) are the receptor-binding and membrane fusion glycoproteins of influenza viruses. They recognize sialic acid-containing, cell-surface glycoconjugates as receptors but have limited affinity for them, and, as a consequence, virus attachment to cells requires their interaction with several virus HAs. Receptor-bound virus is transferred into endosomes where membrane fusion by $\mathrm{HAs}$ is activated at $\mathrm{pH}$ between 5 and 6.5 , depending on the strain of virus. Fusion activity requires extensive rearrangements in HA conformation that include extrusion of a buried "fusion peptide" to connect with the endosomal membrane, form a bridge to the virus membrane, and eventually bring both membranes close together. In this review, we give an overview of the structures of the 16 genetically and antigenically distinct subtypes of influenza A HA in relation to these two functions in virus replication and in relation to recognition of HA by antibodies that neutralize infection.

\section{HEMAGGLUTININ STRUCTURE}

emagglutinins (HAs) project from the virus surface membrane, as 30-50 A-diameter, $135 \AA ̊$ A-long glycoprotein spikes (Wasilewski et al. 2012). Each spike contains three identical subunits formed of two glycopolypeptides, HA1 and HA2. The subunits are divided into four subdomains: the membrane-distal receptorbinding subdomain and the inactive, vestigial esterase subdomain of HA1; and the membrane-proximal fusion subdomain, which contains parts of HA1 and HA2, and the membrane anchor subdomain formed by membrane-associated residues of HA2 (Fig. 1).

The receptor-binding subdomain $\mathrm{R}$ contains the receptor-binding site, which is a shal- low depression at the membrane-distal tip of the molecule (Wilson et al. 1981; Rogers et al. 1983; Weis et al. 1988). Its base contains four conserved residues-tyrosine-98, histidine-183, tyrosine-195, and tryptophan-153-linked by hydrogen bonds (see Fig. 2). The site is enclosed by the 130-loop, the 150-loop, the 220-loop, and the 190-helix. Antigenic sites to which antibodies bind to block infectivity either directly or following Fc-receptor recognition, are clustered in and around the receptor-binding site (Knossow and Skehel 2006; Whittle et al. 2011; Xiong et al. 2015; McCarthy et al. 2018). Amino acid substitutions selected by such antibodies can influence both antibody binding and receptor binding. Those that result in the introduction of additional carbohydrate side chains can

Editors: Gabriele Neumann and Yoshihiro Kawaoka

Additional Perspectives on Influenza: The Cutting Edge available at www.perspectivesinmedicine.org

Copyright (C) 2020 Cold Spring Harbor Laboratory Press; all rights reserved

Advanced Online Article. Cite this article as Cold Spring Harb Perspect Med doi: 10.1101/cshperspect.a038638 
S.J. Gamblin et al.
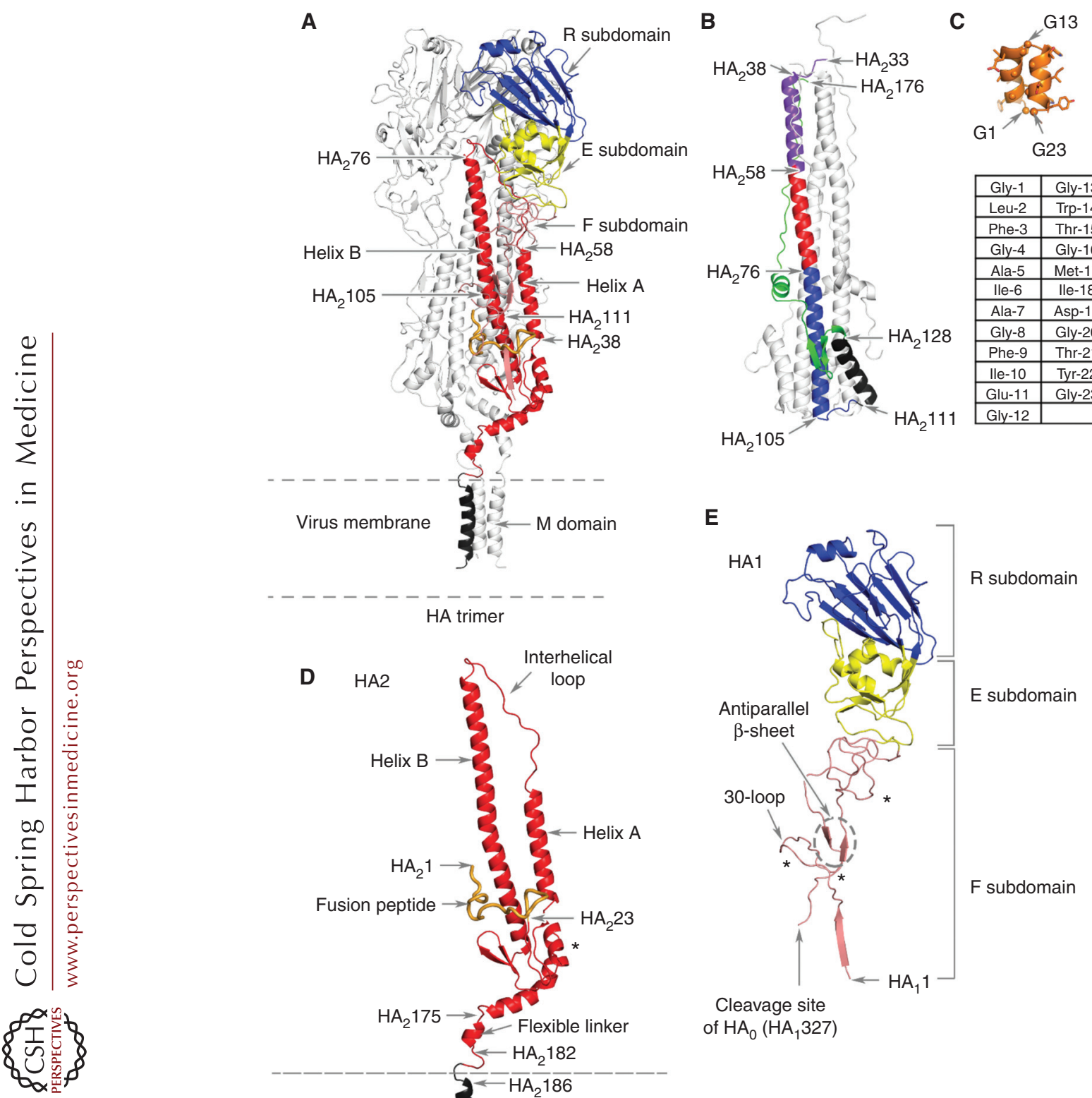

\begin{tabular}{|c|c|}
\hline Gly-1 & Gly-13 \\
\hline Leu-2 & Trp-14 \\
\hline Phe-3 & Thr-15 \\
\hline Gly-4 & Gly-16 \\
\hline Ala-5 & Met-17 \\
\hline Ile-6 & Ile-18 \\
\hline Ala-7 & Asp-19 \\
\hline Gly-8 & Gly-20 \\
\hline Phe-9 & Thr-21 \\
\hline Ile-10 & Tyr-22 \\
\hline Glu-11 & Gly-23 \\
\hline Gly-12 & \\
\hline
\end{tabular}

\section{E}
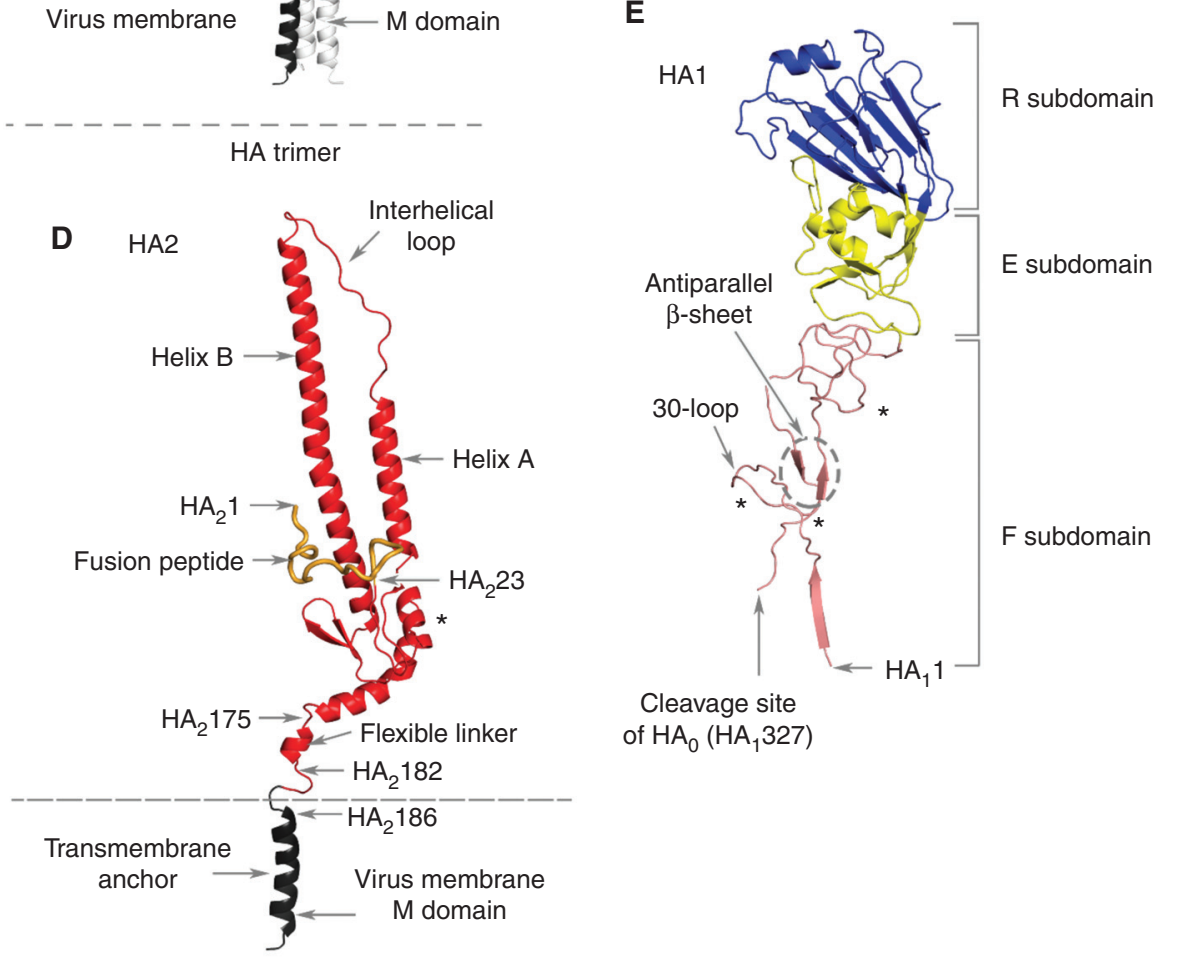

Figure 1. The polypeptide and subdomain structure of hemagglutinin (HA). (A) An HA trimer of the H1 subtype with one subunit colored according to subdomains with the other two subunits in silver. From membrane-distal to membrane-anchor subdomains: the receptor-binding subdomain (blue), the vestigial esterase subdomain (yellow), the fusion subdomain (red), and the membrane anchor subdomain (black). (B) The fusion $\mathrm{pH}$ structure of an (X-31) H3 subtype HA2 expressed in Escherichia coli (Chen et al. 1999). Membrane fusion by influenza viruses is activated at acidic $\mathrm{pH}$, in the case of $\mathrm{X}-31$ at $\mathrm{pH}$ 5.6, and changes in the conformation of $\mathrm{HA} 2$ required for fusion result in the formation of this structure. The color code indicates the positions of the relocated helix- $\mathrm{A}$ (purple), the interhelical loop (red), and the coiled-coil component of helix B (blue) (which is unchanged from its conformation at neutral $\mathrm{pH})$. (Legend continued on following page.) 
have particularly important consequences for both activities (Marinina et al. 2003; Lin et al. 2012; Yang et al. 2015).

\section{THE VESTIGIAL ESTERASE SUBDOMAIN, E}

The vestigial esterase subdomain $\mathrm{E}$ is named for its similarity to part of the 9-O-acetylase of the hemagglutinin-esterase-fusion glycoprotein of influenza $\mathrm{C}$ virus, which is the evolutionary precursor of influenza A (Rosenthal et al. 1998). In influenza $\mathrm{C}$, the esterase functions as a receptor-destroying enzyme, analogous to the sialic acid-receptor-destroying enzymes, the neuraminidases, of influenza A and B viruses (Colman 1994). The E subdomain, which has no esterase activity, links the $\mathrm{R}$ subdomain to the HA1 component of the fusion subdomain (Fig. 1). Structurally, several loops from E interact with the interhelical loop in the fusion subdomain (Fig. 1E).

\section{THE FUSION SUBDOMAIN, F}

The amino terminus of HA1 located in the $\mathrm{F}$ subdomain is the membrane-proximal component of the HA ectodomain, formed by the removal of the biosynthetic signal sequence during virus replication (McCauley et al. 1979; Porter et al. 1979). Amino-terminal residues of HA1 form one strand of a five-stranded, membrane-proximal $\beta$-sheet in each subunit of the trimer, following which the 30-loop inserts between and packs against the central $\alpha$-helices (B-helices) of the subdomain. HA1 then extends toward the membrane-distal part of the molecule, antiparallel with its carboxy-terminal residues (Fig. 1E). The HA1 chain forms the E and the $\mathrm{R}$ subdomains before it returns to $\mathrm{F}$ and terminates at the site of proteolytic cleavage of HA0, the biosynthetic precursor of HA1 and HA2 (Fig. 1E; Chen et al. 1998; Böttcher-Friebartshäuser et al. 2013). Cleavage is essential for membrane fusion activity and virus infectivity (Klenk et al. 1975; Lazarowitz and Choppin 1975).

The major components of the F subdomain are contributed by HA2 (Fig. 1D). The hydrophobic amino-terminal region of HA2 is buried in the trimer interface, $\sim 30 \AA$ from the virus membrane (Wilson et al. 1981; Chen et al. 1998). The 23 amino-terminal residues are called the fusion peptide because of their assumed direct role in membrane fusion. They are linked to one of two antiparallel strands of a membrane-proximal, five-stranded $\beta$-sheet that is joined to $\alpha$-helix A. The $\alpha$-helix A is the shorter helix of a central $\alpha$-helical hairpinlike structure that is the most prominent structural feature of $\mathrm{F}$. The hairpin itself is formed by a 17-residue-long extended chain, called the interhelical loop, that links the carboxyl terminus of the shorter $\alpha$-helix A, to the amino terminus of the longer $\alpha$-helix B. In their amino-terminal,

Figure 1. (Continued.) The turn formed by residues 105-111 positions the carboxy-terminal region of helix B (black) and the carboxy-terminal components of the ectodomain, residues 129-176 (green), antiparallel to the central, $100 \AA$ A coiled-coil. Neither the fusion peptide nor the membrane anchor regions are components of this structure, but they would both be positioned at the same $(t o p)$ end of the coiled-coil. $(C)$ The structure of a synthetic 23-residue fusion peptide (orange), determined by nuclear magnetic resonance (NMR) (Lorieau et al. 2010), indicates that a monomer peptide forms a hairpin-like structure made of two antiparallel helices that turn around conserved glycine-13. Three of the seven conserved glycine residues in the peptide are indicated, as are the surface locations of large side-chain hydrophobic residues, eight of which are completely conserved. The sequence of the peptide is shown in the table below the structure. (D) The HA2 polypeptide from $A$ showing (i) the interhelical loop, (ii) the 23-residue-long fusion peptide at the amino terminus (in orange), (iii) the flexible linker of the ectodomain to the membrane anchor, and (iv) the location of the single carbohydrate side chain (marked by $^{*}$ ). (E) The HA1 polypeptide component of the colored monomer from A showing (i) the HA1 region of the fusion subdomain with its amino terminus near the virus membrane, (ii) the site of cleavage of the precursor HA0 that generates the carboxyl terminus of HA1 and the amino terminus of HA2, (iii) the antiparallel strands of the $\beta$-sheet and the extended chains in the fusion subdomain, and (iv) the locations of the carbohydrate side chains $\left(\right.$ marked by ${ }^{*}$ ). 
S.J. Gamblin et al.
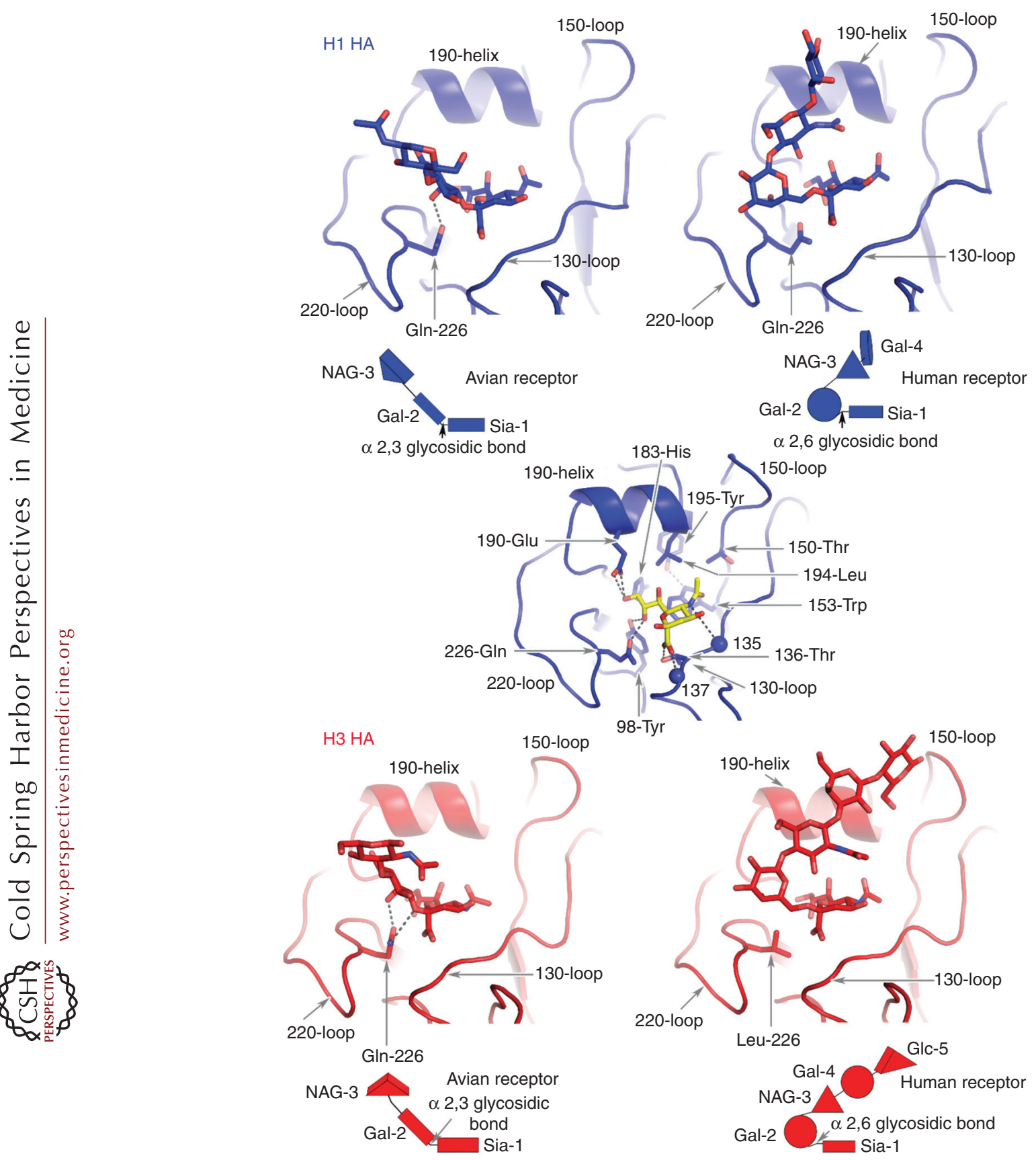

Figure 2. Avian and human receptor analogs complexed with Group 1 and Group $2 \mathrm{HAs}$ represented by $\mathrm{H} 1$ and $\mathrm{H} 3$ HAs. The saccharide composition of the receptors is shown schematically below each panel. The two types of receptors are distinguished by the $\alpha-2,3$ (avian) and $\alpha-2,6$ (human) linkages between sialic acid and the second saccharide, galactose. Different avian species also prefer oligosaccharides with different linkages between Gal-2 and GlcNAc-3. Wild ducks, for example, prefer Gal-2 b1,3-linked GlcNAc-3, whereas domesticated poultry prefer Gal-2 b1-4 GlcNAc-3-linked sialosides (Gambaryan et al. 2008). In the central panel sialic acid (yellow) forms hydrogen bonds between its carboxylate and the hydroxyl of Thr-136 and the peptide amide of residue 137, and between the nitrogen of the acetamido substituent and the carbonyl of residue 135. (Legend continued on following page.) 
Hemagglutinin Structure and Activities

membrane-distal regions, the B helices form an eight-turn, trimeric coiled-coil that opens, as the $\alpha$-helices extend back toward the membrane-associated region into a tripod-like structure (Fig. 1D). The fusion peptide inserts between the three helices of the tripod $\sim 20 \AA$ beneath the carboxyl terminus of the coiled-coil.

Attached to the carboxyl termini of the B helices, two antiparallel $\beta$-strands complete the five-stranded membrane-proximal $\beta$-sheet. The sheet is linked to a short $\alpha$-helix that joins the 160-helix that is oriented almost parallel to the virus membrane. The 160-helix links the ectodomain to the membrane anchor subdomain through an eight-residue flexible linker between two glycine residues (Benton et al. 2018).

\section{THE MEMBRANE ANCHOR SUBDOMAIN, M}

The major component of $\mathrm{M}$ is a triple-helical structure, residues 185-204 of each subunit of the trimer. The helices splay apart at an angle of $\sim 60^{\circ}$ at the carboxyl terminus of the coil (Fig. 1D; Benton et al. 2018). The structures of the six remaining residues of $\mathrm{M}$ and the 11 carboxyterminal residues of HA2 that are outside the virus membrane have not been determined.

\section{STRUCTURAL COMPARISONS}

Most of the information on the structures of HAs have been obtained by X-ray crystallography using crystals formed of soluble ectodomains, obtained by proteolytic removal of the membrane anchor subdomains (Brand and Skehel 1972) (used, e.g., in Wilson et al. 1981; Ha et al. 2001; Gamblin et al. 2004; Stevens et al.
2004; Liu et al. 2009) or by expression of truncated cDNA (e.g., Chen et al. 1995, in bacterial cells; Chen et al. 1998, in mammalian cells; and Xiong et al. 2013a,b, in insect cells). The structure of the complete HA was determined by cryo-electron microscopy (Benton et al. 2018). In addition to revealing the structure of the $M$ subdomain, this complete HA structure indicates that the isolated ectodomains retain their three-dimensional structures independently of the membrane anchor, as concluded before from spectroscopic analyses (Flanagan and Skehel 1977).

\section{GROUP-SPECIFIC STRUCTURAL FEATURES}

Antigenically (WHO 1980), genetically (Air 1981), and structurally (Ha et al. 2002; Russell et al. 2004) the 16 HA subtypes form two groups with three clades in Group 1 and two in Group 2 (Fig. 3A). Structurally, HAs of all 16 subtypes are very similar (e.g., Ha et al. 2002; Russell et al. 2004; Liu et al. 2009; Lu et al. 2013; Vachieri et al. 2014; Tzarum et al. 2015, 2017; Song et al. 2017) and the structures of the four individual subdomains are, for the most part, conserved (Fig. 3B). However, differences in the orientations of the membrane-distal $\mathrm{R}$ and $\mathrm{E}$ subdomains relative to the membrane-proximal $\mathrm{F}$ subdomain are among the most prominent group-specific structural differences between HAs (Fig. 3; Table 1; Ha et al. 2001). They seem to derive primarily from differences in the structure of the interhelical loops of the F subdomain connecting the carboxyl terminus of helix $\mathrm{A}$ and the amino terminus of helix $\mathrm{B}$, and from interactions between the loops and the E and F subdomains of the same and neighboring subunits.

Figure 2. (Continued.) The methyl group of the acetamido makes hydrophobic contacts in a pocket formed of Leu194, Trp-153, and Ile-155. The HAs of the pandemic viruses of 1957 (H2) and 1968 (H3) contained Leu-226 instead of the avian-specific Gln-226 of their proposed avian precursors. In the 1918, 1977, and $2009 \mathrm{H} 1$ pandemic viruses, in contrast, Gln-226 was retained and substitutions Glu190Asp and Gly225Asn correlated with the receptor-binding specificity change to a preference for human receptor. In the characteristic avian receptor-binding motif (Ha et al. 2001) Gln-226 forms hydrogen bonds with the 4-hydroxyl group of Gal-2 and with the glycosidic oxygen of the $\alpha-2,3$ linkage in the trans conformation. By contrast, the Leu- 226 residue contacts carbon- 6 of Gal-2 in the $\alpha$-2,6- linkage in the cis configuration of the human receptor. The $\alpha-2,3-$ linked avian receptor analogs extend linearly from Gal-2 out of the site between the 190-helix and the 220-loop. Again, by contrast, the $\alpha$-2,6-linked human receptor analog following Gal-2 bends back to different extents over sialic acid. 
S.J. Gamblin et al.

A

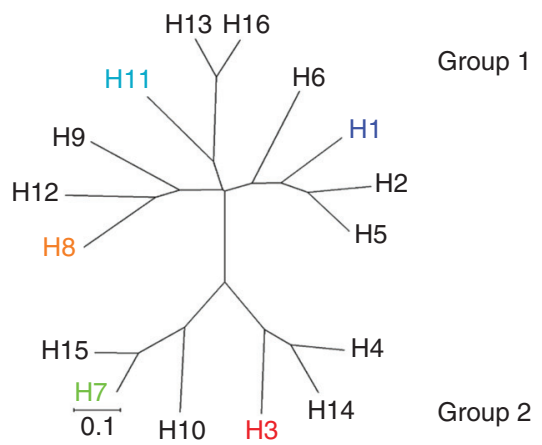

B

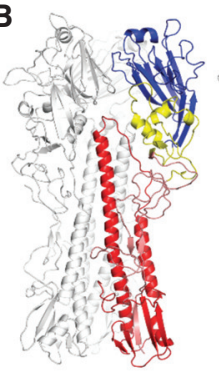

$\mathrm{H} 1$

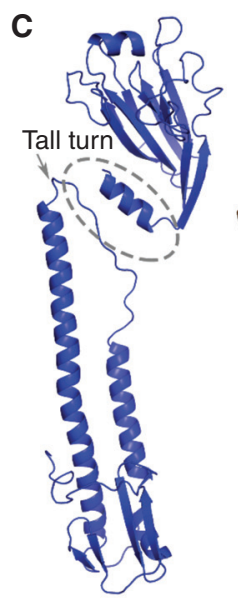

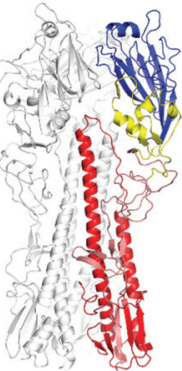

H8

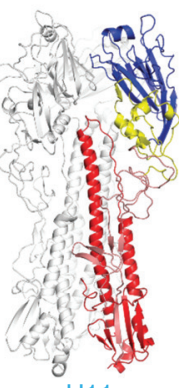

$\mathrm{H} 11$

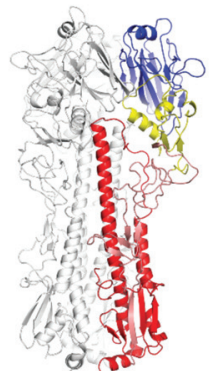

$\mathrm{H} 3$

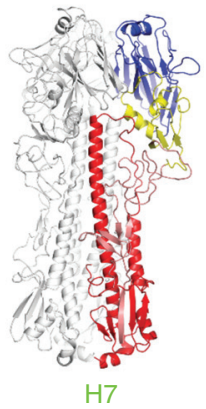

190-helix
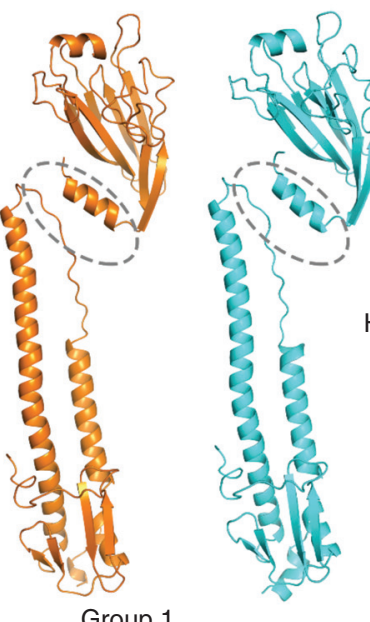

(क) 140-loop

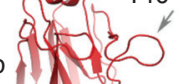

Sharp

turn
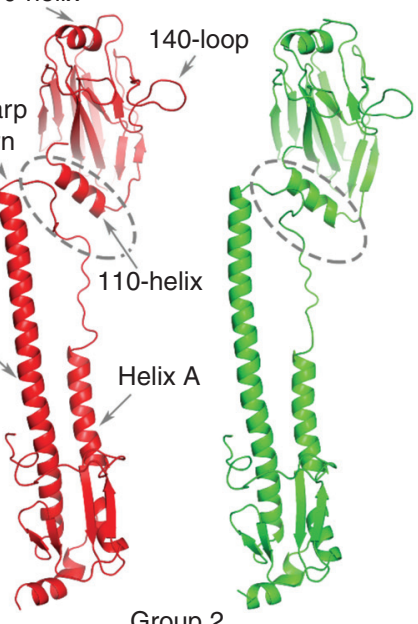

Figure 3. Sequence and structural similarity of HAs in the five clades. (A) Genetic relationships between HAs of the 16 subtypes of influenza A showing the three clades of Group 1 and the two clades of Group 2. (B) HA trimers and $(C)$ HA monomers of the five clades compared. One representative of each clade is shown-H1, H8, and H11 of Group 1 and $\mathrm{H} 3$ and $\mathrm{H} 7$ of Group 2. Of note are the shorter helix A in Group $2 \mathrm{HAs}$; the sharp turn at the carboxyl terminus of the interhelical loop in Group 2 HAs and the tall turn in Group 1 HAs; the rotation of Group 1 membrane-distal subdomains relative to those of Group 2 HAs, noticeable from the orientation of the 190helices at the membrane-distal tip of each subunit, and for the prominent 140-loop on the right side of Group 2 HAs; and the relative proximity of the 110-helix of the esterase subdomain to the interhelical loop in Group 2 HAs. 
Hemagglutinin Structure and Activities

Table 1. Differences in orientation between the subdomains of hemaglutinins (HAs) of different subtypes

\begin{tabular}{|c|c|c|c|c|c|}
\hline $\begin{array}{l}\mathrm{HA} \\
\text { groups }\end{array}$ & HA clades & HA subtypes & $\begin{array}{c}\text { Rotation angle of } \\
\text { R domain }\end{array}$ & $\begin{array}{c}\text { Rotation angle of } \\
\text { E domain }\end{array}$ & $\begin{array}{c}\text { Rotation angle of } \\
\text { F domain }\end{array}$ \\
\hline \multirow[t]{18}{*}{ Group 1} & \multirow{6}{*}{$\begin{array}{l}\mathrm{H} 1, \mathrm{H} 2, \mathrm{H} 5, \\
\quad \text { and } \mathrm{H} 6 \text { clade }\end{array}$} & H2 HA vs. H5 HA & 4.0 & 8 & 8.9 \\
\hline & & H2 HA vs. H1 HA & 3.42 & 6.0 & 5.7 \\
\hline & & H5 HA vs. H1 HA & 5.0 & 2.2 & 3.4 \\
\hline & & H6 HA vs. H2 HA & 3.1 & 5.4 & 8.2 \\
\hline & & H6 HA vs. H1 HA & 4.6 & 6.3 & 1.1 \\
\hline & & H6 HA vs. H5 HA & 2.7 & 5.5 & 0.8 \\
\hline & H8, H9, and & H12 HA vs. H8 HA & 7.8 & 7.2 & 3.6 \\
\hline & \multirow[t]{2}{*}{ H12 clade } & H12 HA vs. H9 HA & 2.9 & 4.7 & 0.7 \\
\hline & & H8 HA vs. H9 HA & 10.2 & 11.1 & 1.5 \\
\hline & \multirow{9}{*}{$\begin{array}{l}\text { H11, H13, and } \\
\text { H16 clade }\end{array}$} & H11 HA vs. H16 HA & 10.8 & 9.3 & 4.3 \\
\hline & & H11 HA vs. H13 HA & 9.3 & 9.2 & 4.6 \\
\hline & & H13 HA vs. H16 HA & 2.8 & 0.6 & 1.8 \\
\hline & & H2 HA vs. H11 HA & 2.9 & 6.6 & 7.1 \\
\hline & & H2 HA vs. H8 HA & 3.5 & 5.7 & 5.3 \\
\hline & & H5 HA vs. H9 HA & 12.4 & 17.4 & 7.34 \\
\hline & & H5 HA vs. H13 HA & 15.6 & 18.1 & 6.8 \\
\hline & & H9 HA vs. H13 HA & 6.8 & 5.5 & 1.7 \\
\hline & & H11 HA vs. H8 HA & 3.4 & 1.9 & 1.5 \\
\hline \multirow[t]{7}{*}{ Group 2} & \multirow{3}{*}{$\begin{array}{r}\mathrm{H} 3, \mathrm{H} 4 \text {, and } \\
\text { H14 clade }\end{array}$} & H3 HA vs. H4 HA & 3.0 & 1.9 & 1.4 \\
\hline & & H3 HA vs. H14 HA & 5.0 & 4.4 & 2.7 \\
\hline & & H4 HA vs. H14 HA & 2.0 & 1.9 & 1.5 \\
\hline & \multirow{4}{*}{$\begin{array}{l}\text { H7, H10, and } \\
\text { H15 clade }\end{array}$} & H7 HA vs. H10 HA & 6.35 & 2.1 & 0.6 \\
\hline & & H7 HA vs. H15 HA & 6.52 & 3.8 & 0.3 \\
\hline & & H10 HA vs. H15 HA & 2.58 & 4.5 & 0.7 \\
\hline & & H3 HA vs. H7 HA & 4.56 & 4.8 & 3.5 \\
\hline \multicolumn{2}{|c|}{ Group 1 vs. Group 2} & H3 HA vs. H5 HA & 26.7 & 28 & 10.5 \\
\hline
\end{tabular}

The main elements of structural distinction shared by group members are in the $\mathrm{F}$ subdomain, near the carboxyl terminus of $\alpha$-helix A and near the amino terminus of $\alpha$-helix B.

At the carboxy-terminal region of $\alpha$-helix A in Group 1 HAs, HA2 methionine-59 makes hydrophobic interactions with conserved HA1 phenylalanine-294 and forms the carboxyl terminus of $\alpha$-helix A. The penultimate residue of helix A is conserved lysine-58, which forms a salt bridge with conserved HA2 glutamic acid-97 that helps position the amino-terminal region of the interhelical loop close to $\alpha$-helix B (Fig. 3A).

By comparison, in Group 2 HAs, HA2 threonine-59 is $\sim 7 \AA$ distant from HA1 phenylalanine-294 (Fig. 3A).

These differences between Group 1 and Group 2 HAs at the carboxyl terminus of $\alpha$-helix A correlate with $\alpha$-helix A being one turn longer in Group 1 HAs than in Group 2 and with the interhelical loop being shorter in Group 1 HAs.

At the amino terminus of $\alpha$-helix $B$ in Group1 HAs, conserved glutamic acid-74 forms a salt bridge with Arginine-76 of a neighboring $\alpha$-helix B that cross-links the subunits of the trimer. The tall turns at the carboxyl terminus of the interhelical loop are stabilized by hydrogen bonds between group-specific HA1 glutamic acid-107 (aspartic acid in H8) and the peptide amides of residues 75 and 76 . By contrast, in Group 2 HAs the turn is tighter arising, intriguingly, from clade-specific features.

In clade H3,4,14, of Group 2, the amino terminus of $\alpha$-helix B is glycine- 75 . Because glycine residues can adopt stereochemical conformations not favored for other amino acids, glycine-75 facilitates the formation of sharp turns between the carboxyl termini of the interhelical loops and the amino termini of the B $\alpha$-helices 
S.J. Gamblin et al.

(Fig. 3B). Salt bridges formed between HA2 glutamic acid-74 and arginine-76 of neighboring subunits, as in Group 1 HAs, together with the additional salt bridge formed between arginine76 and clade-specific glutamic acid-81, crosslink the carboxy-terminal region of the loops in all three subunits of the trimer and stabilize this conformation.

A number of interactions involving $\mathrm{H} 3,4,14$ clade-specific charged residues also appear to stabilize the carboxy-terminal region of the interhelical loop by linking it to residues in the $\mathrm{E}$ subdomain.

In clade $H 7,10,15$, the residue at position HA2 75 is not glycine and HA2 76 is not arginine. Nevertheless, a Group 2-specific sharp turn is formed at the amino terminus of $\alpha$-helix $B$ that correlates in this case, with a combination of hydrophobic interactions between nonpolar residues in the interhelical loop and $\alpha$-helix B, and with the aliphatic parts of the side chains of a number of charged HA1 residues. In particular, the sharp turn appears to be secured by conserved phenylalanine HA2 70 of the interhelical loop docking into a cavity edged by these HA1residue side chains and also by a network of salt bridges between HA1 and HA2 (see Fig. 4).

\section{GROUP-SPECIFIC ROTATION OF R AND E SUBDOMAINS RELATIVE TO THE F SUBDOMAIN}

Differences in the conformation of the interhelical loops in HAs of different clades and in interactions made by them are major influences on the different degrees of rotation of the membrane-distal subdomains of the different clades in relation to helices $\mathrm{A}$ and $\mathrm{B}$.

In the amino-terminal region of the interhelical loops, salt bridges and hydrogen bonds formed between loop residues of Group 2 HAs and helix B, together with hydrophobic interactions, are involved in positioning the loops close to helix B (Fig. 3). In addition, the contribution of a strand to the membrane-distal $\beta$-sheet of subdomain F positions the $\beta$-sheet of HA1 close to helix B.

As a consequence, by comparison with Group 1 HAs, the R and E subdomains of Group
2 HAs appear to be rotated around the threefold axis of symmetry (Fig. 3; Table 1). In addition, the positioning of the $\mathrm{F}$ subdomain influences the positions adopted by the Group $2 \mathrm{E}$ and $\mathrm{R}$ subdomains that are closer to the carboxyl terminus of the interhelical loop and the amino terminus of $\alpha$-helix B (Fig. 3B,C). The tall turns of group1 HAs by contrast, are stabilized by interactions between group-specific charged residues that preclude the HA1 110-helix from proximity to $\alpha$-helix B. Conserved serine-107 in the $\mathrm{H} 3,4,14$, clade and alanine-107 in the $\mathrm{H} 7,10,15$ clade, on the other hand, facilitate the positioning of the 110- $\alpha$-helix toward the sharp turn at the amino terminus of $\alpha$-helix $B$ (Fig. 5B).

\section{RECEPTOR-BINDING AFFINITY AND SPECIFICITY}

Binding of viruses to cells to be infected and release of viruses from infected cells involves sialic acid recognition by both glycoproteins of the virus membrane, HA and neuraminidase, respectively. Their specificities and activities are required to be balanced for effective virus infection (Kaverin et al. 1998; Mitnaul et al. 2000; Baigent and McCauley 2001; Wagner et al. 2002).

The antigenic properties of both glycoproteins vary during a pandemic period and their activities can also vary in recognition specificity and specific activity. Because inhibition-based assays of their activities are the standard procedures used to characterize viruses isolated during antigenic drift, information on changes in the activities is essential for correct interpretation of the assay results. In addition, this information is required to identify differences in the activities of the glycoproteins that appear on cross-species transfer of viruses, a process that can be involved in the start of a new pandemic.

The attachment of virus to the surface of a cell is a polyvalent interaction between hemagglutinins on the virus and multiple copies of sialic acid, which is the terminal sugar of many carbohydrate side chains. Numerous studies (Rogers and D’Souza 1989; Connor et al. 1994; 
A

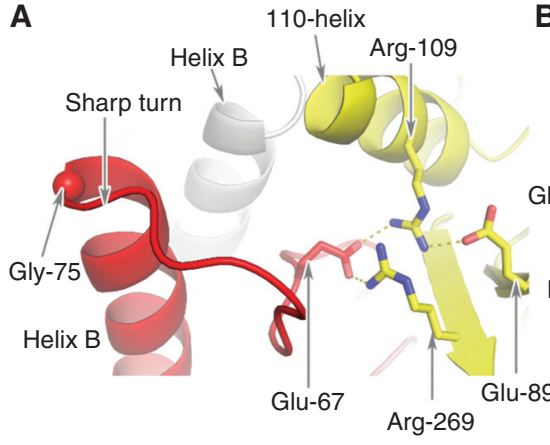

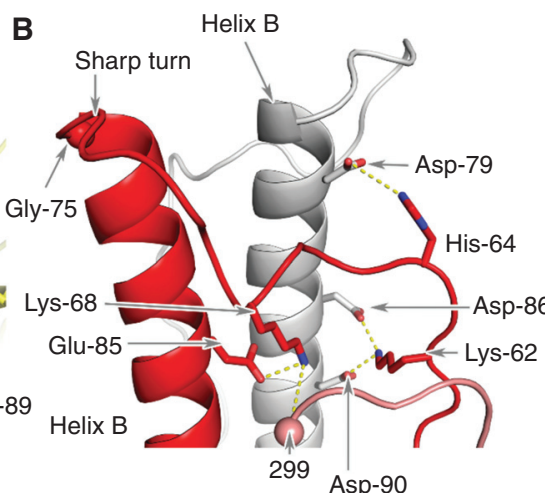

Group 2

H3, H4, H14 Clade
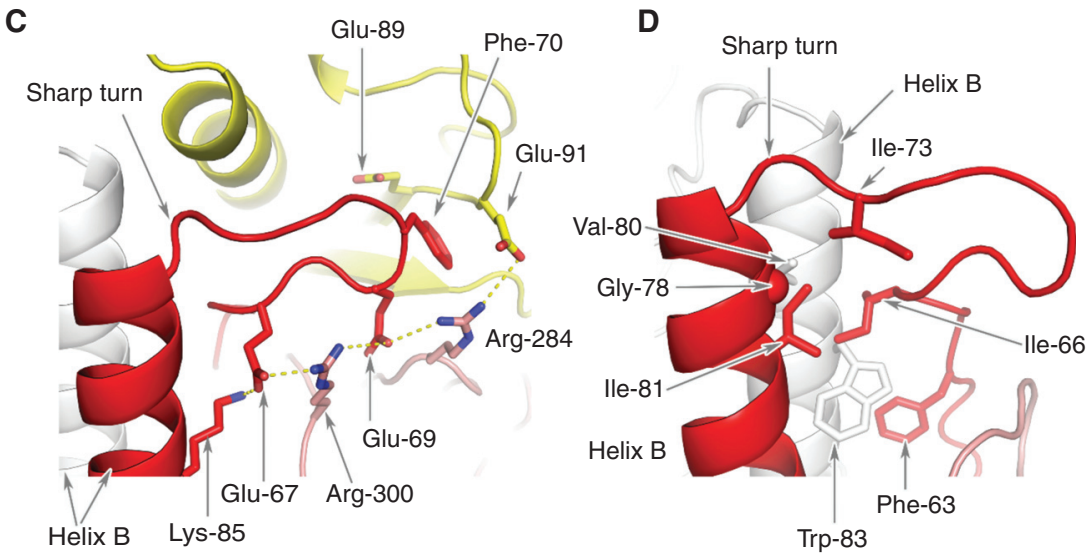

Group 2

$\mathrm{H} 7, \mathrm{H} 10, \mathrm{H} 15$ Clade

Figure 4. Group $2 \mathrm{HA}$ interactions between residues in the interhelical loop, helix B, and the E subdomain. $(A)$ In clade $\mathrm{H} 3,4,14 \mathrm{HAs}$, an intrasubunit network of salt bridges between clade-specific HA2 Glu-67 and E subdomain residues HA1 Arg-109 and Arg-269 in H3 (Lys-269 in H14 and Asn-269 in H4.) HA1 Arg-109 also forms a salt bridge with HA1 Glu-89. (B) In clade H3,4,14 HAs, there are also interactions between Lys-62 of the loop and Asp-86 and Asp-90 of a neighboring helix B. There is an interaction between His-64 and Asp-79 of the same neighboring helix B, and between Lys- 68 and Glu- 85 of helix B of the same subunit. Lys- 68 also interacts with the hydroxyl of residue HA1 299 of the F subdomain antiparallel $\beta$-sheet. $(C)$ The sharp turn at the carboxyl terminus of the interhelical loop of clade H7,10,15 HAs is stabilized by intrasubunit contacts made by Phe-70 in a cavity formed by the aliphatic side chains of Glu- 89 and Glu-91 of the E subdomain and Arg-284 of the F subdomain. Arg-284 also makes charged interactions with Glu-91 and Glu-69, and Arg-300 interacts with Glu69 and Glu-67. (D) These contacts are augmented by hydrophobic interactions made by loop residues Phe-63, Ile-66, and Ile-73 (Val in H7 and H15) that pack against the nonpolar residues of helix B, Gly-78 and Ile-81, and Val-80 and Trp-83 of a neighboring helix B.

Gambaryan et al. 1997; Matrosovich et al. 1997; Imai et al. 2012) have shown that sialic acidreceptor binding is species-specific: avian and equine viruses prefer to bind to sialic acid in $\alpha$ 2,3 linkage to galactose, and human viruses prefer $\alpha$-2,6-linked sialic acid. These preferences correlate with observations that there is an abundance of $\alpha$-2,6-linked sialic acids in the upper respiratory tract of humans and of $\alpha$-2,3-linked sialic acids in the intestinal mucosa of birds, the respective primary sites of infection, and with different preferences for cells in the respiratory 
S.J. Gamblin et al.

A
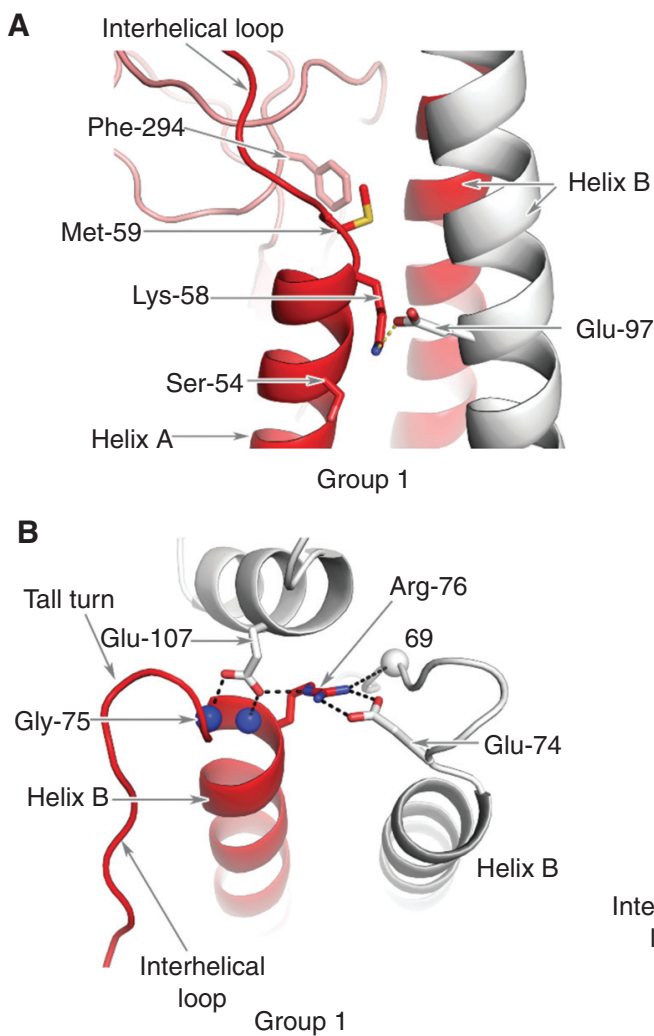

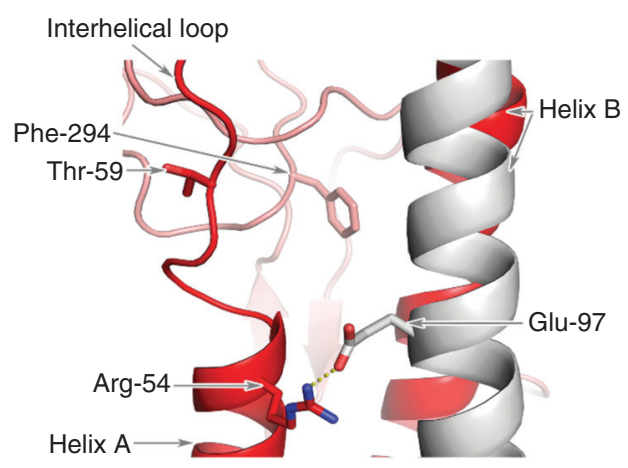

Group 2

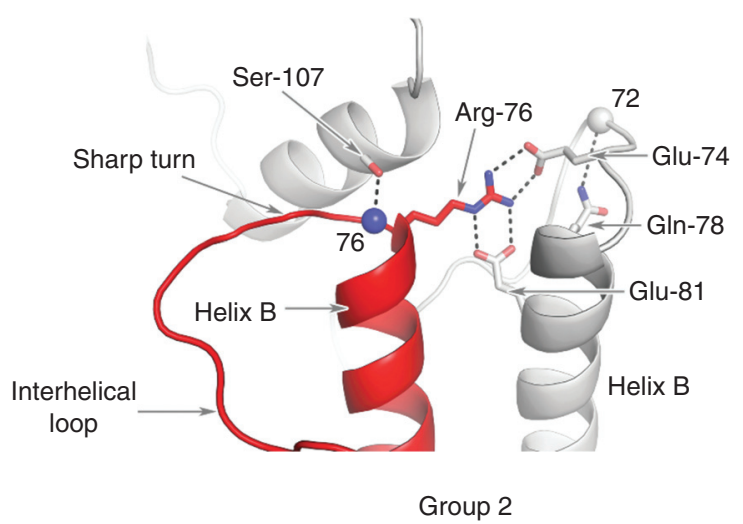

Figure 5. Group-specific structural features at the amino and carboxyl termini of the interhelical loop. (A) A comparison of the structures at the amino termini of the interhelical loops. The interactions of Group 1conserved Met-59 with conserved Phe-294 (left panel) are shown by comparison with the lack of interaction with Group 2-conserved Thr-59 (right panel). In Group 2 HAs of clade 3,4,14 shown here, Group 2-conserved Glu-97 forms a salt bridge with Group 2-conserved Arg-54. In Group 2 clade H7,10,15, Arg-54 forms a salt bridge with conserved Glu-103 (not shown). (B) A comparison of the structures at the carboxyl termini of the interhelical loops indicating the tall turn adopted by Group 1 HAs, which is stabilized by a salt bridge between group-conserved Arg-76 and conserved Glu-107 of a neighboring subunit and by hydrogen bonds between conserved HA1 Glu-107 and the peptide amides of residues 75 and 76 and between Arg-76 and the carbonyl of residue 69. In Group $2 \mathrm{HAs}$ clade 3,4,14, by contrast, the carboxyl terminus of the loop forms a sharp turn to the amino terminus of helix B, stabilized by salt bridges between group-conserved Arg-76 and conserved Glu-74 and clade-specific Glu-81 and a hydrogen bond between clade-specific Ser-107 and peptide amide 76 and between clade-specific Gln-78 and the peptide carbonyl of residue 72 . None of these interactions are formed by clade H7, 10,15 HAs.

tract (Ito et al. 1998; Matrosovich et al. 2004; Shinya et al. 2006; van Riel et al. 2007).

Although other factors may be important, the avidity of a virus for a cell surface coated with sialic acid receptors is directly related to the affinity of individual HA binding sites for the particular sialic acid receptor. It is known that binding of receptor analogs to individual HAs is relatively weak; nuclear magnetic reso- nance (NMR) measurements (Sauter et al. 1989; Hanson et al. 1992) give equilibrium dissociation constants (Kd) for the HA of a human $\mathrm{H} 3$ virus of $\sim 2 \mathrm{mM}$ for $\alpha-2,6$ sialyllactose (human receptor) and $3 \mathrm{mM}$ for $\alpha-2,3$ sialyllactose (avian receptor). For mutant HAs with a Leu$226 \rightarrow$ Gln substitution in the 220-loop of the receptor-binding site (Fig. 2) that was shown to influence binding specificity (Rogers et al. 1983, 
1985) and also to have been observed early in the $\mathrm{H} 2$ and $\mathrm{H} 3$ pandemics (Matrosovich et al. 2000), the values were $\sim 6 \mathrm{mM}$ for human and $3 \mathrm{mM}$ for avian receptors. The Leu- $226 \rightarrow$ Gln mutation, expected to make the HA more avian-like, has only a small effect in changing a 1.5-fold preference for human receptors to a twofold preference for avian receptors. Similar results have been obtained using microscale thermophoresis (MST) with these and other HAs (Benton et al. 2015). For example, Kds have been determined for an avian H5 HA of $20 \mathrm{mM}$ for human receptor and $1 \mathrm{mM}$ for avian receptor (Xiong et al. 2013a).

The weak interactions, consistently detected by such methods, could give rise to very tight binding of viruses as a result of polyvalency. However, given the levels of discrimination frequently observed between human and avian receptors and the hundreds of HAs on the surface of a virus, it is unclear how species specificity would be achieved. Biolayer interferometry has been used to address this question using a range of virus concentrations and varying the amounts of receptor analog on the sensor.

Plots of the transformed data (Benton et al. 2015) are used to calculate an apparent avidity for the virus $K d_{\text {(virus) }}$ at different loadings of receptor analog.

Treating virus binding as an example of a polyvalent interaction, it can be assumed that virus avidity is related to the affinity of a receptor analog for an HA in the following way:

$$
K d_{(\text {Virus })}=K d_{(\text {receptor })}^{\mathrm{mc}},
$$

where $K d_{\text {(receptor) }}$ is the equilibrium dissociation constant for the binding of a receptor analog to $\mathrm{HA}$ and the term mc is a multiplicity coefficient that represents an average for the number and strength of individual HAs interacting with sialic acid. Using $K d_{\text {(virus) }}$ values calculated at a number of different receptor analog loadings and $K d_{\text {(receptor) }}$ values derived from NMR and MST measurements, $\mathrm{mc}$ reaches a maximum value of 5.4 at saturating receptor analog loading. This value indicates an upper limit for the number and strength of HA interactions that can be made with a receptor analog-loaded surface and is ultimately related to the size of the footprint that the virus can make. It does not mean that only five HA-sialic acid interactions are made but that multiple successive interactions become less effective in stabilizing binding-a common observation with polyvalent interactions.

The same procedures can be used to estimate the preferences of a given virus for different receptors. For example, (1) the data for individual human $\mathrm{H} 3$ HAs suggest virus binding values of $3.47 \mathrm{fM}$ for human receptor and $917 \mathrm{fM}$ for avian receptor, a difference in affinity of 265-fold (Benton et al. 2015), and (2) for an $\mathrm{H} 5$ virus binding to a saturated surface where $\mathrm{mc}=5.4$, the calculated $K d_{\text {(virus) }}$ values would be $0.87 \mathrm{nM}$ and $0.1 \mathrm{fM}$ for human and avian receptors, respectively, a difference in affinity of $\sim 8$ millionfold. Consistent with these values, binding of the $\mathrm{H} 5$ virus to surfaces coated with human receptor is only just detectable at very high receptor analog loadings (Xiong et al. 2013a).

For interspecies transmission, as noted above, it is generally the case that avian viruses do not readily infect humans. This is thought to be due at least in part to the fact that avian viruses bind with low affinity to sialic acids of the human receptors found in the upper respiratory tract of humans. This is consistent with the above analyses showing that avian $\mathrm{H} 5$ virus binds very weakly to a sensor surface fully saturated with human receptor but very strongly to a surface coated with avian receptor.

However, from transmission experiments that used an avian $\mathrm{H} 5$ virus to infect ferrets as surrogate humans (Imai et al. 2012), MST data for the HA of a ferret-transmissible mutant H5 virus that was isolated show that its affinity for human receptors is only slightly increased (Xiong et al. 2013a). The $K d_{\text {(receptor) }}$ of the transmissible mutant HA for the human receptor is $13 \mathrm{mM}$ compared with $21 \mathrm{mM}$ for the wild-type (wt) avian $\mathrm{H} 5 \mathrm{HA}$, a 1.6-fold change in $K d_{\text {(receptor) }}$ that would result in a 13 -fold difference in $K d_{\text {(virus) }}$ for binding to human receptor. However, the affinity for avian receptors was more significantly reduced to $K d_{\text {(receptor) }} 32$ $\mathrm{mM}$ for the mutant, compared to $1.1 \mathrm{mM}$ for 
S.J. Gamblin et al.

the wt HA. Would the modest increase in affinity, if replicated by the virus interaction with a human cell surface, be sufficient to explain the transmissibility of this mutant virus to humans? Or is the more dramatic reduction in the affinity for avian receptors more likely to be involved, by allowing the virus to evade capture by $\alpha-2,3$ linked sialic acids on respiratory secretions (Couceiro et al. 1993)? Perhaps a combination of both effects is required.

Quantitative studies of receptor binding of this sort have been accompanied by extensive analysis of specificity using array technologies that display large numbers of potential sialoside receptors derived from biological sources or produced synthetically (Blixt et al. 2004; Feizi and Chai 2004; Gao et al. 2019). These arrays have been particularly useful recently in analyzing the receptor-binding properties of viruses isolated in different stages of a pandemic, at which times, receptor-binding variants are initially manifested by decreases in the affinities of viruses for erythrocytes of different species, in hemagglutination tests (Lin et al. 2012). They have, for example, shown the preference of H1- and H3-subtype human viruses for branched glycans with branches consisting of sialylated poly- $N$-acetyl-lactosamine repeats that might interact at more than one binding site on a hemagglutinin simultaneously (Peng et al. 2017; Byrd-Leotis et al. 2019).

Microarrays have also been used to display and identify potential ligands extracted from human, ferret, and porcine lung tissues (Walther et al. 2013; Byrd-Leotis et al. 2014, 2019). With these preparations it has again been seen that viruses from different species, or with differing antigenic properties, have different binding specificities. In addition, using such arrays it is reported that viruses also bound to nonsialylated, phosphorylated glycans (Byrd-Leotis et al. 2019). Both areas of research, whether or not the receptors identified as branched chain sialosides or as phosphorylated glycans are physiologically involved, provide an important focus for research on the nature of the receptors involved in influenza virus-cell interactions in vivo.

Additional information on recognition specificity and its molecular basis has been obtained from X-ray crystallographic and NMR analyses, and from molecular dynamics simulations of HA-sialoside complexes (Weis et al. 1988; Sauter et al. 1992; Eisen et al. 1997; Ha et al. 2001, 2003; Russell et al. 2006; Lin et al. 2012; Xu et al. 2012; Xiong et al. 2013a,b; Collins et al. 2014; Macchi et al. 2016). These studies indicate that the sialic acid moiety of the receptor interacts through hydrogen bonds between its carboxylate and hydroxylated amino acids at residues 136 and 137 of the 130-loop, between the peptide carbonyl of residue 135 and the amide of the $\mathrm{N}$-acetamido substituent, between the glutamate or aspartate at residue 190 of the 190-helix and the 9-hydroxyl group of the glycerol substituent, and between the hydroxyl group of tyrosine-98 and the 8-hydroxyl of the glycerol substituent (Fig. 2). The importance of these interactions has also been studied by analyses of site-specific mutant HAs (Martín et al. 1998; Meisner et al. 2008). Although sialic acid occupies the binding site of these complexes in very similar ways independently of the nature of the other sugar components of the receptor analogs, and essentially the same for all viruses, the positions of the other saccharides of the bound sialosides show greater positional variation ( $\mathrm{Ha}$ et al. 2001; Gamblin et al. 2004; Russell et al. 2006; Xiong et al. 2014). Specifically, $\alpha-2,3-$ linked glycans extend linearly from sialic acid, leaving the binding site between the amino terminus of the 190-helix and the carboxyl terminus of the 220-loop (Fig. 2). The orientations of all avian receptors bound to avian HAs are strikingly similar. In contrast, $\alpha$-2,6-linked derivatives bound to human HAs are folded over the bound sialic acid, to different degrees depending on the particular subtype of HA (Fig. 2).

As noted before, changes in the specificity and affinity of viruses for receptors occur as a consequence of mutations in and around the receptor-binding site that are selected by the pressure of growth requirements in cells with different surface sialosides during transfer of viruses between species or by the immune pressure that occurs as viruses spread during a pandemic. In the former, changes in the 190-helix and the 220-loop (Fig. 1) have been observed in early pandemic viruses compared with their pu- 
Hemagglutinin Structure and Activities

tative avian precursors, and the consequences for binding specificity changes have been reported (Matrosovich et al. 2000; Ha et al. 2003).

Changes that occur during a pandemic as a consequence of antigenic drift, are an indication of the importance of the inhibition of receptor binding by antibodies, as a mechanism of neutralizing virus infectivity.

\section{MEMBRANE FUSION}

\section{Priming by Precursor Cleavage}

The structure of the translation product of the gene for HA, HA0, differs from that of HA at the site of cleavage of its subunits into HAl and HA2 (Chen et al. 1998). Cleavage, which is required for infectivity, involves cellular proteases (Böttcher-Friebartshäuser et al. 2013; Limburg et al. 2019) and produces the carboxyl terminus of HA1 and the amino terminus of HA2. The amino-terminal 23-residues of HA2 are known as the fusion peptide (Fig. 1D).

On cleavage, the fusion peptide refolds and inserts into a charged cavity in the center of the HA trimer. Three ionizable residues are buried in the process: in Group 1 HAs, Asp-109, Asp112, and His-111, and in Group 2 HAs, Asp109, Asp-112, and His 17. The differences in structure between HAO and HA as a consequence of this rearrangement are confined to 19 residues out of a total of 549 in each subunit, but they correlate with differences in trimer stability-HA0 Tm, 50 HA Tm, $62^{\circ}$ (Ruigrok et al. 1986; Carr et al. 1997; Skehel et al. 2008). Cleavage primes $\mathrm{HA}$ for activation at low $\mathrm{pH}$ in endosomes. The conformation of uncleaved $\mathrm{H} 3$ $\mathrm{HA} 0$ appears unresponsive to changes in $\mathrm{pH}$.

\section{Changes in HA Conformation at Low pH}

Activation of HA fusion potential occurs between $\mathrm{pH} 5.0$ and 6.5 depending on the strain of virus. At this low $\mathrm{pH}$, HA refolds extensively and irreversibly. It becomes susceptible to proteolysis, and X-ray crystallographic analysis of proteolytic fragments or equivalent expression products support conclusions from biochemical, antigenic, and electron microscopic studies on the nature of the changes and their consequences (Bullough et al. 1994; Chen et al. 1999). They indicate that the membrane-distal subdomains of HA detrimerize but otherwise retain their neutral pH structure (Bizebard et al. 1995) and that the fusion peptide is released from its buried location to become the amino terminus of a new coiled-coil of $\alpha$-helices (Fig. 1B; Bullough et al. 1994; Chen et al. 1999). Analysis of the final product of HA2 refolding shows that the fusion peptide and the membrane anchor are colocated at one end of a $110 \AA$-long, rodlike structure, following a $180^{\circ}$ turn between residues HA2 106 and 111 in helix B (Fig. 1). This irreversibly refolded structure is the most stable of the different conformations of HA studied, with a thermal denaturation temperature of $80^{\circ}$. Neutral $\mathrm{pH}$, cleaved HA with a Tm of $62^{\circ}$ is, therefore, intermediate in stability between $\mathrm{HA} 0, \mathrm{Tm} 50^{\circ}$ and fusion $\mathrm{pH} \mathrm{HA}, \mathrm{Tm} 80^{\circ}$ (Ruigrok et al. 1986; Skehel et al. 2008; Kim et al. 2011).

EM analysis of virus fusion with liposomes (Calder and Rosenthal 2016) indicates that 200 A-long structures formed at fusion $\mathrm{pH}$ by HA, bridge virus, and liposome membranes. They may be intermediates in the formation of the $110 \AA$ rods before the $180^{\circ}$ turn at HA2 residues $106-111$ is formed. A coiled structure of this sort was initially predicted from sequence analyses (Ward and Dopheide 1980) and subsequently was suggested to be formed at low $\mathrm{pH}$, from studies of synthetic peptides containing the sequence of the interhelical loop (Carr and Kim 1993). Current interest in the process of refolding is focused on the identification and characterization of possible intermediates by biophysical techniques (Garcia et al. 2015; Das et al. 2018) and by EM (Fontana and Steven 2012; Calder and Rosenthal 2016).

The fusion peptide itself has not been observed as a component of fusion $\mathrm{pH}$ HA fragments. However, NMR studies of 23-residue fusion peptide analogs (Lorieau et al. 2010, 2012) indicate that, in detergent solution, the peptides form hairpin-like structures of two antiparallel helices. The turn of the hairpin is at glycine-13 with the remaining conserved glycine residues (Skehel and Waterfield 1975; Cross et al. 2009) 
S.J. Gamblin et al.

arranged as components of the inner surfaces of both helices of the hairpin (Fig. 1C). As part of fusion-active HA, the individual fusion peptides of the HA trimer may adopt a similar helical structure.

Considerations of possible requirements for HA refolding in the mechanism of membrane fusion have been based, first, on the observation that both the carboxy-terminal membrane anchor and amino-terminal fusion peptide of HA2 are colocated at one end of the fusion $\mathrm{pH}$ HA structure. This has led to the suggestion that HA refolding may be required to bring virus and cellular membranes close enough to each other to facilitate their fusion. Second, formation of the long coiled-coil is proposed to deliver the fusion peptide at its amino terminus to the membrane to be fused, and in its fusion-active form, the fusion peptide may directly alter the structure of the lipid bilayer to facilitate fusion (Chernomordik and Kozlov 2003; Kim et al. 2011).

From analyses of EM and X-ray crystallographic structures it is also possible to postulate that both ends of the structures, the fusion peptide and the membrane anchor subdomain, may be required to be flexibly linked to HA. The available information indicates that this may be so. The membrane anchor at the carboxyl terminus of full-length, neutral $\mathrm{pH}$ HA is seen in different images by cryo-EM to be flexibly linked to the ectodomain (Fig. 1; Benton et al. 2018). In the case of the $110 \AA$ rod-like structure of HA2 (Fig. 1), which lacks the membrane anchor and the fusion peptide, the electron density maps are not interpretable between the amino terminus of the expressed construct, HA2-23, and the amino terminus of the observed trimeric coiled-coil, HA2-38 (Chen et al. 1999). This suggests that the region immediately carboxyterminal to the fusion peptide in intact HA may also be flexible.

\section{Antigenicity}

The amino acid sequences of HAs of antigenic variants selected by growth of viruses in the presence of monoclonal antibodies (Gerhard and Webster 1978) have been used to map the molecular locations at which the mutations occur that are responsible for the changes in antigenicity. Most frequently, the mutants contain single amino acid substitutions, sometimes resulting in the introduction of an additional carbohydrate side chain (Caton et al. 1982; Skehel et al. 1984; Knossow and Skehel 2006). EM (Wrigley et al. 1983; Liu et al. 2017; Benton et al. 2018; Turner et al. 2019), and X-ray crystallographic analyses of HA in complexes with Fab fragments from monoclonal antibodies (Bizebard et al. 1995; Knossow and Skehel 2006) indicate that the positions of the substitutions define the sites of antibody binding (Fig. 6). The sites are mainly on the R subdomain (Figs. 1 and 6), which has been interpreted to indicate that the mechanisms by which the antibodies neutralize virus infectivity is either directly or indirectly, by blocking sialic acid-receptor binding (Knossow et al. 2002). The majority of antibodies of this sort that have been reported are strain-specific. However, some of them are able to prevent infection by viruses within a subtype, by binding either directly into the receptorbinding site, or to separate sites on the membrane-distal surface of R (Whittle et al. 2011; Ekiert et al. 2012; Xiong et al. 2015; Wang et al. 2019) or to sites in the interface between monomers in the HA trimer (Bangaru et al. 2019; Watanabe et al. 2019).

In contrast to complexes formed by Fabs of the subtype-specific antibodies, complexes formed by HAs with Fabs from a number of antibodies that block infections by all viruses of Group 1 or Group 2 or of both Group1 and Group 2 (Corti et al. 2017) reveal that they interact with the $\mathrm{F}$ subdomain near the fusion peptide (Fig. 6). In vitro these antibodies block the conformational changes in HA required for membrane fusion and can also prevent cleavage of the HA0 precursor. In these ways they may inhibit virus replication. However, the HA-antibody complexes that they form are recognized in vivo by Fc receptor-bearing immune cells that lyse infected cells (Corti et al. 2011; DiLillo et al. 2014), and this may be the mechanism of antiviral activity of this group of cross-reactive antibodies. Information gained from analyses of 
Hemagglutinin Structure and Activities

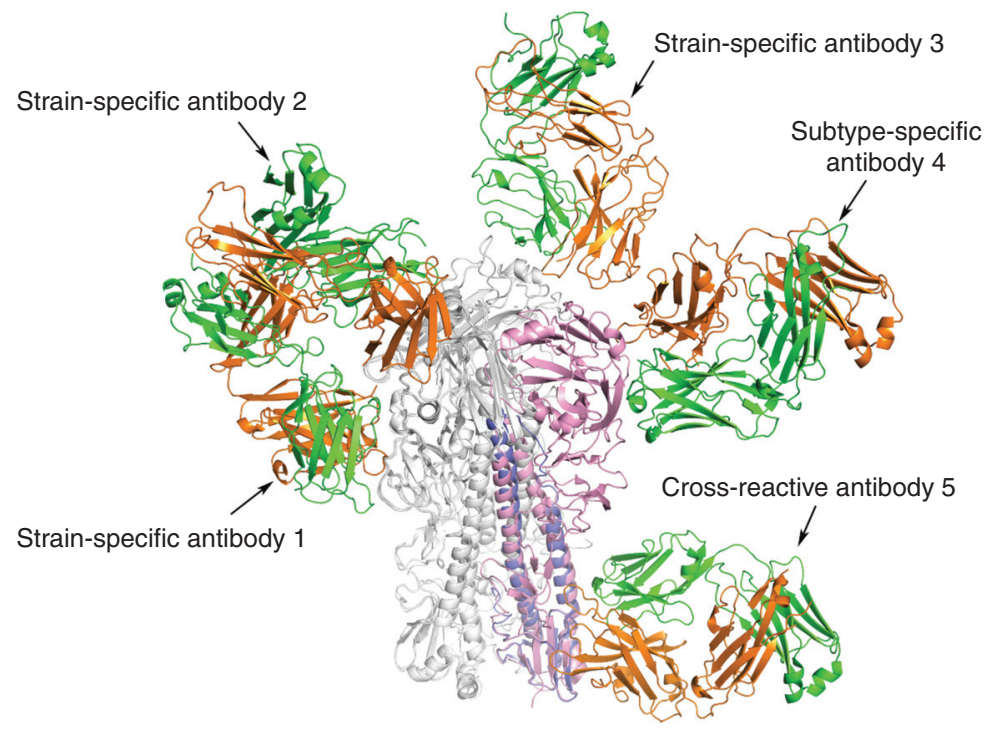

Figure 6. Examples of the sites of binding of anti-HA monoclonal antibodies. The structures of complexes formed by Fabs of five monoclonal antibodies that were determined by X-ray crystallography illustrate the regions of HA recognized by antibodies that block infection. Antibodies 1, 2, and 3 bind in or near the receptor-binding site of HA. Antibodies 2 and 3 directly block receptor binding and are strain-specific. Other antibodies of this type with longer HCDR3 loops that penetrate the site can be cross-reactive within a subtype (Whittle et al. 2011; Ekiert et al. 2012). Antibody 1 binds $\sim 15 \AA$ below the site and is less effective at blocking receptor binding. It may do so by projecting the Fc portion of the antibody over the receptor-binding site and sterically preventing receptor access. Antibody 4 binds at a similar distance from the site to antibody 1, but to the molecular surface behind the receptor-binding pocket. It also does not directly prevent receptor binding, but it blocks infection by all viruses in the $\mathrm{H} 5$ subtype. Cross-reactive antibody 5 binds near the fusion peptide and in vitro can block HA0 cleavage and also prevent the conformational change in HA required for fusion. It blocks infection by viruses of Group 1 and Group 2 as a result of immune cytolysis following recognition of the bound antibody by Fc receptor-bearing cells. Antibody 4 may block infection in a similar manner. Antibodies 1, 2, and 3 are from mice immunized with HA from the H3 subtype (Bizebard et al. 1995; Knossow et al. 2002). Antibodies 4 and 5 were isolated from immunized humans (Corti et al. 2011; Xiong et al. 2015; Kallewaard et al. 2016).

such antibodies, in particular those that recognize all viruses within a subtype, are valuable for research programs that have the objective of developing immunotherapies (Corti et al. 2017) or immunogens that could induce cross-reactive antibodies by vaccination (Krammer and Palese 2013) or identifying broad spectrum antiviral molecules (van Dongen et al. 2019), all to overcome the current unpredictability of influenza outbreaks and pandemics.

\section{ACKNOWLEDGMENT}

This article has been made freely available online courtesy of TAUNS Laboratories.

\section{REFERENCES}

Air GM. 1981. Sequence relationships among the hemagglutinin genes of 12 subtypes of influenza A virus. Proc Natl Acad Sci 78: 7639-7643. doi:10.1073/pnas.78.12.7639

Baigent SJ, McCauley JW. 2001. Glycosylation of haemagglutinin and stalk-length of neuraminidase combine to regulate the growth of avian influenza viruses in tissue culture. Virus Res 79: 177-185. doi:10.1016/S0168-1702 (01)00272-6

Bangaru S, Lang S, Schotsaert M, Vanderven HA, Zhu X, Kose N, Bombardi R, Finn JA, Kent SJ, Gilchuk P, et al. 2019. A site of vulnerability on the influenza virus hemagglutinin head domain trimer interface. Cell 177: 11361152.e18. doi:10.1016/j.cell.2019.04.011

Benton DJ, Martin SR, Wharton SA, McCauley JW. 2015. Biophysical measurement of the balance of influenza $\mathrm{A}$ hemagglutinin and neuraminidase activities. J Biol Chem 290: 6516-6521. doi:10.1074/jbc.M114.622308 
S.J. Gamblin et al.

Benton DJ, Nans A, Calder LJ, Turner J, Neu U, Lin YP, Ketelaars E, Kallewaard NL, Corti D, Lanzavecchia A, et al. 2018. Influenza hemagglutinin membrane anchor. Proc Natl Acad Sci 115: 10112-10117. doi:10.1073/pnas .1810927115

Bizebard T, Gigant Bt, Rigolet P, Rasmussen B, Diat O, Bösecke P, Wharton SA, Skehel JJ, Knossow M. 1995. Structure of influenza virus haemagglutinin complexed with a neutralizing antibody. Nature 376: 92-94. doi:10.1038/ 376092a0

Blixt O, Head S, Mondala T, Scanlan C, Huflejt ME, Alvarez R, Bryan MC, Fazio F, Calarese D, Stevens J, et al. 2004. Printed covalent glycan array for ligand profiling of diverse glycan binding proteins. Proc Natl Acad Sci 101: 17033-17038. doi:10.1073/pnas.0407902101

Böttcher-Friebertshäuser E, Klenk HD, Garten W. 2013. Activation of influenza viruses by proteases from host cells and bacteria in the human airway epithelium. Pathog Dis 69: 87-100. doi:10.1111/2049-632X.12053

Brand CM, Skehel JJ. 1972. Crystalline antigen from the influenza virus envelope. Nat New Biol 238: 145-147. doi:10.1038/newbio238145a0

Bullough PA, Hughson FM, Skehel JJ, Wiley DC. 1994 Structure of influenza haemagglutinin at the $\mathrm{pH}$ of membrane fusion. Nature 371: 37-43. doi:10.1038/371037a0

Byrd-Leotis L, Liu R, Bradley KC, Lasanajak Y, Cummings SF, Song X, Heimburg-Molinaro J, Galloway SE, Culhane MR, Smith DF, et al. 2014. Shotgun glycomics of pig lung identifies natural endogenous receptors for influenza viruses. Proc Natl Acad Sci 111: E2241-E2250. doi:10.1073/ pnas. 1323162111

Byrd-Leotis L, Jia N, Dutta S, Trost JF, Gao C, Cummings SF, Braulke T, Müller-Loennies S, Heimburg-Molinaro J, Steinhauer DA, et al. 2019. Influenza binds phosphorylated glycans from human lung. Sci $A d v$ 5: eaav2554 doi:10.1126/sciadv.aav2554

Calder LJ, Rosenthal PB. 2016. Cryomicroscopy provides structural snapshots of influenza virus membrane fusion. Nat Struct Mol Biol 23: 853-858. doi:10.1038/nsmb.3271

Carr CM, Kim PS. 1993. A spring-loaded mechanism for the conformational change of influenza hemagglutinin. Cell 73: 823-832. doi:10.1016/0092-8674(93)90260-W

Carr CM, Chaudhry C, Kim PS. 1997. Influenza hemagglutinin is spring-loaded by a metastable native conformation. Proc Natl Acad Sci 94: 14306-14313. doi:10.1073/ pnas.94.26.14306

Caton AJ, Brownlee GG, Yewdell JW, Gerhard W. 1982. The antigenic structure of the influenza virus $\mathrm{A} / \mathrm{PR} / 8 / 34 \mathrm{hem}$ agglutinin (H1 subtype). Cell 31: 417-427. doi:10.1016/ 0092-8674(82)90135-0

Chen J, Wharton SA, Weissenhorn W, Calder LJ, Hughson FM, Skehel JJ, Wiley DC. 1995. A soluble domain of the membrane-anchoring chain of influenza virus hemagglutinin (HA2) folds in Escherichia coli into the low-pHinduced conformation. Proc Natl Acad Sci 92: 1220512209. doi:10.1073/pnas.92.26.12205

Chen J, Lee KH, Steinhauer DA, Stevens DJ, Skehel JJ, Wiley DC. 1998. Structure of the hemagglutinin precursor cleavage site, a determinant of influenza pathogenicity and the origin of the labile conformation. Cell 95: 409417. doi:10.1016/S0092-8674(00)81771-7
Chen J, Skehel JJ, Wiley DC. 1999. N- and C-terminal residues combine in the fusion-pH influenza hemagglutinin $\mathrm{HA}_{2}$ subunit to form an $\mathrm{N}$ cap that terminates the triplestranded coiled coil. Proc Natl Acad Sci 96: 8967-8972. doi:10.1073/pnas.96.16.8967

Chernomordik LV, Kozlov MM. 2003. Protein-lipid interplay in fusion and fission of biological membranes. Annu Rev Biochem 72: 175-207. doi:10.1146/annurev.biochem .72 .121801 .161504

Collins PJ, Vachieri SG, Haire LF, Ogrodowicz RW, Martin SR, Walker PA, Xiong X, Gamblin SJ, Skehel JJ. 2014. Recent evolution of equine influenza and the origin of canine influenza. Proc Natl Acad Sci 111: 11175-11180. doi:10.1073/pnas.1406606111

Colman PM. 1994. Influenza virus neuraminidase: structure, antibodies, and inhibitors. Protein Sci 3: 1687-1696. doi:10.1002/pro.5560031007

Connor RJ, Kawaoka Y, Webster RG, Paulson JC. 1994. Receptor specificity in human, avian, and equine $\mathrm{H} 2$ and $\mathrm{H} 3$ influenza virus isolates. Virology 205: 17-23. doi:10.1006/ viro.1994.1615

Corti D, Voss J, Gamblin SJ, Codoni G, Macagno A, Jarrossay D, Vachieri SG, Pinna D, Minola A, Vanzetta F, et al 2011. A neutralizing antibody selected from plasma cells that binds to group 1 and group 2 influenza A hemagglutinins. Science 333: 850-856. doi:10.1126/science .1205669

Corti D, Cameroni E, Guarino B, Kallewaard NL, Zhu Q, Lanzavecchia A. 2017. Tackling influenza with broadly neutralizing antibodies. Curr Opin Virol 24: 60-69. doi:10.1016/j.coviro.2017.03.002

Couceiro JNSS, Paulson JC, Baum LG. 1993. Influenza virus strains selectively recognize sialyloligosaccharides on human respiratory epithelium; the role of the host cell in selection of hemagglutinin receptor specificity. Virus Res 29: 155-165. doi:10.1016/0168-1702(93)90056-S

Cross KJ, Langley WA, Russell RJ, Skehel JJ, Steinhauer DA. 2009. Composition and functions of the influenza fusion peptide. Protein Pept Lett 16: 766-778. doi:10.2174/ 092986609788681715

Das DK, Govindan R, Nikić-Spiegel I, Krammer F, Lemke EA, Munro JB. 2018. Direct visualization of the conformational dynamics of single influenza hemagglutinin trimers. Cell 174: 926-937.e12. doi:10.1016/j.cell.2018.05.050

DiLillo DJ, Tan GS, Palese P, Ravetch JV. 2014. Broadly neutralizing hemagglutinin stalk-specific antibodies require Fc $\gamma \mathrm{R}$ interactions for protection against influenza virus in vivo. Nat Med 20: 143-151. doi:10.1038/nm.3443

Eisen MB, Sabesan S, Skehel JJ, Wiley DC. 1997. Binding of the influenza A virus to cell-surface receptors: structures of five hemagglutinin-sialyloligosaccharide complexes determined by x-ray crystallography. Virology 232: 1931. doi:10.1006/viro.1997.8526

Ekiert DC, Kashyap AK, Steel J, Rubrum A, Bhabha G, Khayat R, Lee JH, Dillon MA, O’Neil RE, Faynboym AM, et al. 2012. Cross-neutralization of influenza A viruses mediated by a single antibody loop. Nature 489: 526-532. doi:10.1038/nature11414

Feizi T, Chai W. 2004. Oligosaccharide microarrays to decipher the glyco code. Nat Rev Mol Cell Biol 5: 582-588. doi: $10.1038 / \mathrm{nrm} 1428$ 
Flanagan MT, Skehel JJ. 1977. The conformation of influenza virus haemagglutinin. FEBS Lett 80: 57-60. doi:10 .1016/0014-5793(77)80406-7

Fontana J, Steven AC. 2015. Influenza virus-mediated membrane fusion: structural insights from electron microscopy. Arch Biochem Biophys 581: 86-97. doi:10.1016/j.abb 2015.04.011

Gambaryan AS, Tuzikov AB, Piskarev VE, Yamnikova SS, Lvov DK, Robertson JS, Bovin NV, Matrosovich MN 1997. Specification of receptor-binding phenotypes of influenza virus isolates from different hosts using synthetic sialylglycopolymers: non-egg-adapted human $\mathrm{H} 1$ and $\mathrm{H} 3$ influenza A and influenza B viruses share a common high binding affinity for $6^{\prime}$-sialyl( $N$-acetyllactosamine). Virology 232: 345-350. doi:10.1006/viro.1997.8572

Gambaryan A, Tuzikov AB, Pazynina GV, Desheva JA, Bovin NV, Matrosovich MN, Klimov AI. 2008. 6-Sulpho sialyl Lewis $\mathrm{X}$ is the common receptor determinant recognized by $\mathrm{H} 5, \mathrm{H} 6, \mathrm{H} 7$, and $\mathrm{H} 9$ influenza viruses of terrestrial poultry. Virol J 5: 85. doi:1186/1743-422X-5-85

Gamblin SJ, Haire LF, Russell RJ, Stevens DJ, Xiao B, Ha Y, Vasisht N, Steinhauer DA, Daniels RS, Elliot A, et al. 2004. The structure and receptor binding properties of the 1918 influenza hemagglutinin. Science 303: 18381842. doi:10.1126/science.1093155

Gao C, Wei M, McKitrick TR, McQuillan AM, HeimburgMolinaro J, Cummings RD. 2019. Glycan microarrays as chemical tools for identifying glycan recognition by immune proteins. Front Chem 7: 833. doi:10.3389/fchem .2019 .00833

Garcia NK, Guttman M, Ebner JL, Lee KK. 2015. Dynamic changes during acid-induced activation of influenza hemagglutinin. Structure 23: 665-676. doi:10.1016/j.str.2015 .02 .006

Gerhard W, Webster RG. 1978. Antigenic drift in influenza A viruses: selection and characterization of antigenic variants of $\mathrm{A} / \mathrm{PR} / 8 / 34$ (H0N1) influenza virus with monoclonal antibodies. J Exp Med 148: 383-392. doi:10.1084/ jem.148.2.383

Ha Y, Stevens DJ, Skehel JJ, Wiley DC. 2001. X-ray structures of $\mathrm{H} 5$ avian and $\mathrm{H} 9$ swine influenza virus hemagglutinins bound to avian and human receptor analogs. Proc Natl Acad Sci 98: 11181-11186. doi:10.1073/pnas.201401198

Ha Y, Stevens DJ, Skehel JJ, Wiley DC. 2002. H5 avian and H9 swine influenza virus haemagglutinin structures: possible origin of influenza subtypes. EMBO J 21: 865-875. doi:10.1093/emboj/21.5.865

Ha Y, Stevens DJ, Skehel JJ, Wiley DC. 2003. X-ray structure of the hemagglutinin of a potential $\mathrm{H} 3$ avian progenitor of the 1968 Hong Kong pandemic influenza virus. Virology 309: 209-218. doi:10.1016/S0042-6822(03)00068-0

Hanson JE, Sauter NK, Skehel JJ, Wiley DC. 1992. Proton nuclear magnetic resonance studies of the binding of sialosides to intact influenza virus. Virology 189: 525-533. doi:10.1016/0042-6822(92)90576-B

Imai M, Watanabe T, Hatta M, Das SC, Ozawa M, Shinya K, Zhong G, Hanson A, Katsura H, Watanabe S, et al. 2012. Experimental adaptation of an influenza H5 HA confers respiratory droplet transmission to a reassortant $\mathrm{H} 5 \mathrm{HA} /$ H1N1 virus in ferrets. Nature 486: 420-428. doi:10.1038/ nature10831
Ito T, Couceiro JNSS, Kelm S, Baum LG, Krauss S, Castrucci MR, Donatelli I, Kida H, Paulson JC, Webster RG, et al. 1998. Molecular basis for the generation in pigs of influenza A viruses with pandemic potential. J Virol 72: 7367. doi:10.1128/JVI.72.9.7367-7373.1998

Kallewaard NL, Corti D, Collins PJ, Neu U, McAuliffe JM, Benjamin E, Wachter-Rosati L, Palmer-Hill FJ, Yuan AQ, Walker PA, et al. 2016. Structure and function analysis of an antibody recognizing all influenza A subtypes. Cell 166: 596-608. doi:10.1016/j.cell.2016.05.073

Kaverin NV, Gambaryan AS, Bovin NV, Rudneva IA, Shilov AA, Khodova OM, Varich NL, Sinitsin BV, Makarova NV, Kropotkina EA. 1998. Postreassortment changes in influenza A virus hemagglutinin restoring HA-NA functional match. Virology 244: 315-321. doi:10.1006/viro.1998.9119

Kim CS, Epand RF, Leikina E, Epand RM, Chernomordik LV. 2011. The final conformation of the complete ectodomain of the HA2 subunit of influenza hemagglutinin can by itself drive low pH-dependent fusion. J Biol Chem 286: 13226-13234. doi:10.1074/jbc.M110.181297

Klenk HD, Rott R, Orlich M, Blödorn J. 1975. Activation of influenza A viruses by trypsin treatment. Virology 68: 426-439. doi:10.1016/0042-6822(75)90284-6

Knossow M, Skehel JJ. 2006. Variation and infectivity neutralization in influenza. Immunology 119: 1-7. doi:10 $.1111 / \mathrm{j} .1365-2567.2006 .02421 . \mathrm{x}$

Knossow M, Gaudier M, Douglas A, Barrère B, Bizebard T, Barbey C, Gigant B, Skehel JJ. 2002. Mechanism of neutralization of influenza virus infectivity by antibodies. $\mathrm{Vi}$ rology 302: 294-298. doi:10.1006/viro.2002.1625

Krammer F, Palese P. 2013. Influenza virus hemagglutinin stalk-based antibodies and vaccines. Curr Opin Virol 3: 521-530. doi:10.1016/j.coviro.2013.07.007

Lazarowitz SG, Choppin PW. 1975. Enhancement of the infectivity of influenza A and B viruses by proteolytic cleavage of the hemagglutinin polypeptide. Virology 68: 440-454. doi:10.1016/0042-6822(75)90285-8

Limburg H, Harbig A, Bestle D, Stein DA, Moulton HM, Jaeger J, Janga H, Hardes K, Koepke J, Schulte L, et al. 2019. TMPRSS2 is the major activating protease of influenza A virus in primary human airway cells and influenza $B$ virus in human type II pneumocytes. J Virol 93: e00649. doi:10.1128/JVI.00649-19

Lin YP, Xiong X, Wharton SA, Martin SR, Coombs PJ, Vachieri SG, Christodoulou E, Walker PA, Liu J, Skehel JJ, et al. 2012. Evolution of the receptor binding properties of the influenza $\mathrm{A}(\mathrm{H} 3 \mathrm{~N} 2)$ hemagglutinin. Proc Natl Acad Sci 109: 21474-21479. doi:10.1073/pnas. 1218841110

Liu J, Stevens DJ, Haire LF, Walker PA, Coombs PJ, Russell RJ, Gamblin SJ, Skehel JJ. 2009. Structures of receptor complexes formed by hemagglutinins from the Asian Influenza pandemic of 1957. Proc Natl Acad Sci 106: 17175 17180. doi:10.1073/pnas.0906849106

Liu Y, Pan J, Jenni S, Raymond DD, Caradonna T, Do KT, Schmidt AG, Harrison SC, Grigorieff N. 2017. CryoEM structure of an influenza virus receptor-binding site antibody-antigen interface. J Mol Biol 429: 1829-1839. doi:10 $.1016 /$ j.jmb.2017.05.011

Lorieau JL, Louis JM, Bax A. 2010. The complete influenza hemagglutinin fusion domain adopts a tight helical hairpin arrangement at the lipid:water interface. Proc Natl Acad Sci 107: 11341-11346. doi:10.1073/pnas.1006142107 
S.J. Gamblin et al.

Lorieau JL, Louis JM, Schwieters CD, Bax A. 2012. pH-triggered, activated-state conformations of the influenza hemagglutinin fusion peptide revealed by NMR. Proc Natl Acad Sci 109: 19994-19999. doi:10.1073/pnas.1213801109

Lu X, Qi J, Shi Y, Wang M, Smith DF, Heimburg-Molinaro J, Zhang Y, Paulson JC, Xiao H, Gao GF. 2013. Structure and receptor binding specificity of hemagglutinin $\mathrm{H} 13$ from avian influenza A virus H13N6. J Virol 87: 90779085. doi:10.1128/JVI.00235-13

Macchi E, Rudd TR, Raman R, Sasisekharan R, Yates EA, Naggi A, Guerrini M, Elli S. 2016. Nuclear magnetic resonance and molecular dynamics simulation of the interaction between recognition protein $\mathrm{H} 7$ of the novel influenza virus $\mathrm{H7N} 9$ and glycan cell surface receptors. Biochemistry 55: 6605-6616. doi:10.1021/acs.biochem .6b00693

Marinina VP, Gambaryan AS, Bovin NV, Tuzikov AB, Shilov AA, Sinitsyn BV, Matrosovich MN. 2003. The effect of losing glycosylation sites near the receptor-binding region on the receptor phenotype of the human influenza virus H1N1. Mol Biol 37: 468-472. doi:10.1023/A :1024207931650

Martín J, Wharton SA, Lin YP, Takemoto DK, Skehel JJ, Wiley DC, Steinhauer DA. 1998. Studies of the binding properties of influenza hemagglutinin receptor-site mutants. Virology 241: 101-111. doi:10.1006/viro.1997.8958

Matrosovich MN, Gambaryan AS, Teneberg S, Piskarev VE, Yamnikova SS, Lvov DK, Robertson JS, Karlsson KA. 1997. Avian influenza A viruses differ from human viruses by recognition of sialyloligosaccharides and gangliosides and by a higher conservation of the HA receptor-binding site. Virology 233: 224-234. doi:10.1006/viro.1997.8580

Matrosovich M, Tuzikov A, Bovin N, Gambaryan A, Klimov A, Castrucci MR, Donatelli I, Kawaoka Y. 2000. Early alterations of the receptor-binding properties of $\mathrm{H} 1, \mathrm{H} 2$, and $\mathrm{H} 3$ avian influenza virus hemagglutinins after their introduction into mammals. J Virol 74: 8502-8512. doi:10.1128/JVI.74.18.8502-8512.2000

Matrosovich MN, Matrosovich TY, Gray T, Roberts NA, Klenk HD. 2004. Human and avian influenza viruses target different cell types in cultures of human airway epithelium. Proc Natl Acad Sci 101: 4620-4624. doi:10.1073/ pnas.0308001101

McCarthy KR, Watanabe A, Kuraoka M, Do KT, McGee CE, Sempowski GD, Kepler TB, Schmidt AG, Kelsoe G, Harrison SC. 2018. Memory B cells that cross-react with group 1 and group 2 influenza A viruses are abundant in adult human repertoires. Immunity 48: 174-184.e9. doi:10.1016/j.immuni.2017.12.009

McCauley J, Bye J, Elder K, Gething MJ, Skehel JJ, Smith A, Waterfield MD. 1979. Influenza virus haemagglutinin signal sequence. FEBS Lett 108: 422-426. doi:10.1016/00145793(79)80578-5

Meisner J, Szretter KJ, Bradley KC, Langley WA, Li ZN, Lee BJ, Thoennes S, Martin J, Skehel JJ, Russell RJ, et al. 2008. Infectivity studies of influenza virus hemagglutinin receptor binding site mutants in mice. J Virol 82: 5079-5083. doi:10.1128/JVI.01958-07

Mitnaul LJ, Matrosovich MN, Castrucci MR, Tuzikov AB, Bovin NV, Kobasa D, Kawaoka Y. 2000. Balanced hemagglutinin and neuraminidase activities are critical for efficient replication of influenza A virus. $J$ Virol 74: 6015-6020. doi:10.1128/JVI.74.13.6015-6020.2000

Peng W, de Vries RP, Grant OC, Thompson AJ, McBride R, Tsogtbaatar B, Lee PS, Razi N, Wilson IA, Woods RJ, et al. 2017. Recent H3N2 viruses have evolved specificity for extended, branched human-type receptors, conferring potential for increased avidity. Cell Host Microbe 21: 23-34. doi:10.1016/j.chom.2016.11.004

Porter AG, Barber C, Carey NH, Hallewell RA, Threlfall G, Emtage JS. 1979. Complete nucleotide sequence of an influenza virus haemagglutinin gene from cloned DNA. Nature 282: 471-477. doi:10.1038/282471a0

Rogers GN, D'Souza BL. 1989. Receptor binding properties of human and animal $\mathrm{H} 1$ influenza virus isolates. Virology 173: 317-322. doi:10.1016/0042-6822(89)90249-3

Rogers GN, Paulson JC, Daniels RS, Skehel JJ, Wilson IA, Wiley DC. 1983. Single amino acid substitutions in influenza haemagglutinin change receptor binding specificity. Nature 304: 76-78. doi:10.1038/304076a0

Rogers GN, Daniels RS, Skehel JJ, Wiley DC, Wang XF, Higa HH, Paulson JC. 1985. Host-mediated selection of influenza virus receptor variants. Sialic acid- $\alpha 2,6 \mathrm{Gal}$-specific clones of A/duck/Ukraine/1/63 revert to sialic acid- $\alpha$ 2,3Gal-specific wild type in ovo. J Biol Chem 260: 7362-7367.

Rosenthal PB, Zhang X, Formanowski F, Fitz W, Wong CH, Meier-Ewert H, Skehel JJ, Wiley DC. 1998. Structure of the haemagglutinin-esterase-fusion glycoprotein of influenza C virus. Nature 396: 92-96. doi:10.1038/23974

Ruigrok RWH, Martin SR, Wharton SA, Skehel JJ, Bayley PM, Wiley DC. 1986. Conformational changes in the hemagglutinin of influenza virus which accompany heat-induced fusion of virus with liposomes. Virology 155: 484-497. doi:10.1016/0042-6822(86)90210-2

Russell RJ, Gamblin SJ, Haire LF, Stevens DJ, Xiao B, Ha Y, Skehel JJ. 2004. H1 and H7 influenza haemagglutinin structures extend a structural classification of haemagglutinin subtypes. Virology 325: 287-296. doi:10.1016/j.virol .2004 .04 .040

Russell RJ, Stevens DJ, Haire LF, Gamblin SJ, Skehel JJ. 2006. Avian and human receptor binding by hemagglutinins of influenza A viruses. Glycoconj J 23: 85-92. doi:10.1007/ s10719-006-5440-1

Sauter NK, Bednarski MD, Wurzburg BA, Hanson JE, Whitesides GM, Skehel JJ, Wiley DC. 1989. Hemagglutinins from two influenza virus variants bind to sialic acid derivatives with millimolar dissociation constants: a 500$\mathrm{MHz}$ proton nuclear magnetic resonance study. Biochemistry 28: 8388-8396. doi:10.1021/bi00447a018

Sauter NK, Glick GD, Crowther RL, Park SJ, Eisen MB, Skehel JJ, Knowles JR, Wiley DC. 1992. Crystallographic detection of a second ligand binding site in influenza virus hemagglutinin. Proc Natl Acad Sci 89: 324-328. doi:10 $.1073 /$ pnas.89.1.324

Shinya K, Ebina M, Yamada S, Ono M, Kasai N, Kawaoka Y. 2006. Influenza virus receptors in the human airway. $\mathrm{Na}$ ture 440: 435-436. doi:10.1038/440435a

Skehel JJ, Waterfield MD. 1975. Studies on the primary structure of the influenza virus hemagglutinin. Proc Natl Acad Sci 72: 93-97. doi:10.1073/pnas.72.1.93

Skehel JJ, Stevens DJ, Daniels RS, Douglas AR, Knossow M, Wilson IA, Wiley DC. 1984. A carbohydrate side chain on hemagglutinins of Hong Kong influenza viruses inhibits 
recognition by a monoclonal antibody. Proc Natl Acad Sci 81: 1779-1783. doi:10.1073/pnas.81.6.1779

Skehel JJ, Wharton S, Calder L, Stevens D. 2008. On the activation of membrane fusion by influenza haemagglutinin. Novel and re-emerging respiratory viral diseases, pp. 56-68. Wiley, Chichester.

Song H, Qi J, Xiao H, Bi Y, Zhang W, Xu Y, Wang F, Shi Y, Gao GF. 2017. Avian to human receptor-binding adaptation by influenza A virus hemagglutinin H4. Cell Rep 20: 1201-1214 doi:10.1016/j.celrep.2017.07.028

Stevens J, Corper AL, Basler CF, Taubenberger JK, Palese P, Wilson IA. 2004. Structure of the uncleaved human H1 hemagglutinin from the extinct 1918 influenza virus. Science 303: 1866-1870. doi:10.1126/science.1093373

Turner HL, Pallesen J, Lang S, Bangaru S, Urata S, Li S, Cottrell CA, Bowman CA, Crowe JE, Wilson IA, et al. 2019. Potent anti-influenza H7 human monoclonal antibody induces separation of hemagglutinin receptor-binding head domains. PLoS Biol 17: e3000139. doi:10.1371/ journal.pbio.3000139

Tzarum N, de Vries RP, Zhu X, Yu W, McBride R, Paulson JC, Wilson IA. 2015. Structure and receptor binding of the hemagglutinin from a human H6N1 influenza virus. Cell Host Microbe 17: 369-376. doi:10.1016/j.chom 2015.02.005

Tzarum N, McBride R, Nycholat CM, Peng W, Paulson JC, Wilson IA. 2017. Unique structural features of influenza virus H15 hemagglutinin. J Virol 91: e00046-17. doi:10 1128/JVI.00046-17

Vachieri SG, Xiong X, Collins PJ, Walker PA, Martin SR, Haire LF, Zhang Y, McCauley JW, Gamblin SJ, Skehel JJ. 2014. Receptor binding by H10 influenza viruses. $\mathrm{Na}$ ture 511: 475-477. doi:10.1038/nature13443

van Dongen MJP, Kadam RU, Juraszek J, Lawson E, Brandenburg B, Schmitz F, Schepens WBG, Stoops B, van Diepen HA, Jongeneelen M, et al. 2019. A small-molecule fusion inhibitor of influenza virus is orally active in mice. Science 363: eaar6221. doi:10.1126/science.aar6221

van Riel D, Munster VJ, de Wit E, Rimmelzwaan GF, Fouchier RAM, Osterhaus ADME, Kuiken T. 2007. Human and avian influenza viruses target different cells in the lower respiratory tract of humans and other mammals. Am Pathol 171: 1215-1223. doi:10.2353/ajpath.2007.070248

Wagner R, Matrosovich M, Klenk HD. 2002. Functional balance between haemagglutinin and neuraminidase in influenza virus infections. Rev Med Virol 12: 159-166. doi: $10.1002 / \mathrm{rmv} .352$

Walther T, Karamanska R, Chan RWY, Chan MCW, Jia N, Air G, Hopton C, Wong MP, Dell A, Malik Peiris JS, et al. 2013. Glycomic analysis of human respiratory tract tissues and correlation with influenza virus infection. PLoS Pathog 9: e1003223. doi:10.1371/journal.ppat.1003223

Wang P, Zuo Y, Sun J, Zuo T, Zhang S, Guo S, Shi X, Liang M, Zhou P, Zhang L, et al. 2019. Structural and functional definition of a vulnerable site on the hemagglutinin of highly pathogenic avian influenza A virus H5N1. J Biol Chem 294: 4290-4303. doi:10.1074/jbc.RA118.007008

Ward CW, Dopheide T. 1980. Influenza virus haemagglutinin. Structural predictions suggest that the fibrillar appearance is due to the presence of a coiled-coil. Aust $J$ Biol Sci 33: 441-448. doi:10.1071/BI9800441
Wasilewski S, Calder LJ, Grant T, Rosenthal PB. 2012. Distribution of surface glycoproteins on influenza A virus determined by electron cryotomography. Vaccine 30: 7368-7373. doi:10.1016/j.vaccine.2012.09.082

Watanabe A, McCarthy KR, Kuraoka M, Schmidt AG, Adachi Y, Onodera T, Tonouchi K, Caradonna TM, Bajic G, Song S, et al. 2019. Antibodies to a conserved influenza head interface epitope protect by an IgG subtype-dependent mechanism. Cell 177: 1124-1135.e16. doi:10.1016/j .cell.2019.03.048

Weis W, Brown JH, Cusack S, Paulson JC, Skehel JJ, Wiley DC. 1988. Structure of the influenza virus haemagglutinin complexed with its receptor, sialic acid. Nature 333: 426431. doi:10.1038/333426a0

Whittle JRR, Zhang R, Khurana S, King LR, Manischewitz J, Golding H, Dormitzer PR, Haynes BF, Walter EB, Moody MA, et al. 2011. Broadly neutralizing human antibody that recognizes the receptor-binding pocket of influenza virus hemagglutinin. Proc Natl Acad Sci 108: 1421614221. doi:10.1073/pnas.1111497108

Wilson IA, Skehel JJ, Wiley DC. 1981. Structure of the haemagglutinin membrane glycoprotein of influenza virus at $3 \AA$ resolution. Nature 289: 366-373. doi:10.1038/ $289366 \mathrm{a} 0$

World Health Organization (WHO). 1980. A revision of the system of nomenclature for influenza viruses: a WHO memorandum. Bull World Health Organ 58: 585-591.

Wrigley NG, Brown EB, Daniels RS, Douglas AR, Skehel JJ, Wiley DC. 1983. Electron microscopy of influenza haemagglutinin-monoclonal antibody complexes. Virology 131: 308-314. doi:10.1016/0042-6822(83)90499-3

Xiong X, Coombs PJ, Martin SR, Liu J, Xiao H, McCauley JW, Locher K, Walker PA, Collins PJ, Kawaoka Y, et al. 2013a. Receptor binding by a ferret-transmissible H5 avian influenza virus. Nature 497: 392-396. doi:10.1038/na ture 12144

Xiong X, Martin SR, Haire LF, Wharton SA, Daniels RS, Bennett MS, McCauley JW, Collins PJ, Walker PA, Skehe JJ, et al. 2013b. Receptor binding by an H7N9 influenza virus from humans. Nature 499: 496-499. doi:10.1038/ nature 12372

Xiong X, McCauley JW, Steinhauer DA. 2014. Receptor binding properties of the influenza virus hemagglutinin as a determinant of host range. Curr Top Microbiol Immunol 385: 63-91. doi:10.1007/82_2014_423

Xiong X, Corti D, Liu J, Pinna D, Foglierini M, Calder LJ, Martin SR, Lin YP, Walker PA, Collins PJ, et al. 2015. Structures of complexes formed by $\mathrm{H} 5$ influenza hemagglutinin with a potent broadly neutralizing human monoclonal antibody. Proc Natl Acad Sci 112: 9430-9435. doi:10.1073/pnas.1510816112

Xu R, McBride R, Nycholat CM, Paulson JC, Wilson IA 2012. Structural characterization of the hemagglutinin receptor specificity from the $2009 \mathrm{H} 1 \mathrm{~N} 1$ influenza pandemic. J Virol 86: 982-990. doi:10.1128/JVI.06322-11

Yang H, Carney PJ, Chang JC, Guo Z, Villanueva JM, Stevens J. 2015. Structure and receptor binding preferences of recombinant human $\mathrm{A}(\mathrm{H} 3 \mathrm{~N} 2)$ virus hemagglutinins. Virology 477: 18-31. doi:10.1016/j.virol.2014 .12 .024 


\section{$\&_{\mathrm{CSH}}^{\infty} \&$ Cold Spring Harbor

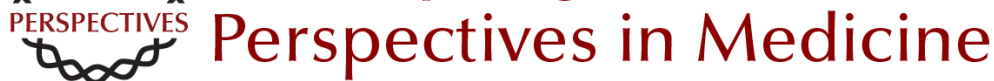

\section{Hemagglutinin Structure and Activities}

Steven J. Gamblin, Sébastien G. Vachieri, Xiaoli Xiong, Jie Zhang, Stephen R. Martin and John J. Skehel

Cold Spring Harb Perspect Med published online June 8, 2020

\section{Subject Collection Influenza: The Cutting Edge}

\section{Emerging HxNy Influenza A Viruses William J. Liu, Yan Wu, Yuhai Bi, et al. \\ Equine Influenza \\ Thomas M. Chambers \\ Human Influenza Epidemiology \\ Sukhyun Ryu and Benjamin J. Cowling}

Host Cell Factors That Interact with Influenza

Virus Ribonucleoproteins

Ecco Staller and Wendy S. Barclay

Induction and Evasion of Type-I Interferon

Responses during Influenza A Virus Infection

Raquel Muñoz-Moreno, Carles Martínez-Romero and Adolfo García-Sastre

Structure and Function of Influenza Polymerase Joanna M. Wandzik, Tomas Kouba and Stephen Cusack

H7N9 Influenza Virus in China Chengjun Li and Hualan Chen

H5 Influenza Viruses in Egypt Rabeh El-Shesheny, Ahmed Kandeil, Ahmed Mostafa, et al. Antivirals Targeting the Neuraminidase
Larisa Gubareva and Teena Mohan

Accessory Gene Products of Influenza A Virus Rute M. Pinto, Samantha Lycett, Eleanor Gaunt, et al.

Influenza Immunization in the Context of

Preexisting Immunity Susanne L. Linderman, Ali H. Ellebedy, Carl Davis, et al.

Hemagglutinin Structure and Activities Steven J. Gamblin, Sébastien G. Vachieri, Xiaoli Xiong, et al.

Live Attenuated Cold-Adapted Influenza Vaccines Kanta Subbarao

Next-Generation Influenza Vaccines Masaru Kanekiyo and Barney S. Graham

\section{Selective Genome Packaging Mechanisms of Influenza A Viruses Takeshi Noda}

Systems Biological Analysis of Immune Response to Influenza Vaccination Mario Cortese, Amy C. Sherman, Nadine G. Rouphael, et al.

For additional articles in this collection, see http://perspectivesinmedicine.cshlp.org/cgi/collection/ 